\title{
Tectonic evolution and mantle structure of the Caribbean
}

\author{
Steven van Benthem, ${ }^{1}$ Rob Govers, ${ }^{1}$ Wim Spakman, ${ }^{1}$ and Rinus Wortel ${ }^{1}$ \\ Received 18 July 2012; revised 25 May 2013; accepted 31 May 2013; published 28 June 2013.
}

[1] We investigate whether predictions of mantle structure from tectonic reconstructions are in agreement with a detailed tomographic image of seismic $P$ wave velocity structure under the Caribbean region. In the upper mantle, positive seismic anomalies are imaged under the Lesser Antilles and Puerto Rico. These anomalies are interpreted as remnants of Atlantic lithosphere subduction and confirm tectonic reconstructions that suggest at least $1100 \mathrm{~km}$ of convergence at the Lesser Antilles island arc during the past $\sim 45 \mathrm{Myr}$. The imaged Lesser Antilles slab consists of a northern and southern anomaly, separated by a low-velocity anomaly across most of the upper mantle, which we interpret as the subducted North America-South America plate boundary. The southern edge of the imaged Lesser Antilles slab agrees with vertical tearing of South America lithosphere. The northern Lesser Antilles slab is continuous with the Puerto Rico slab along the northeastern plate boundary. This results in an amphitheater-shaped slab, and it is interpreted as westward subducting North America lithosphere that remained attached to the surface along the northeastern boundary of the Caribbean plate. At the Muertos Trough, however, material is imaged until a depth of only $100 \mathrm{~km}$, suggesting a small amount of subduction. The location and length of the imaged South Caribbean slab agrees with proposed subduction of Caribbean lithosphere under the northern South America plate. An anomaly related to proposed Oligocene subduction at the Nicaragua rise is absent in the tomographic model. Beneath Panama, a subduction window exists across the upper mantle, which is related to the cessation of subduction of the Nazca plate under Panama since $9.5 \mathrm{Ma}$ and possibly the preceding subduction of the extinct Cocos-Nazca spreading center. In the lower mantle, two large anomaly patterns are imaged. The westernmost anomaly agrees with the subduction of Farallon lithosphere. The second lower mantle anomaly is found east of the Farallon anomaly and is interpreted as a remnant of the late Mesozoic subduction of North and South America oceanic lithosphere at the Greater Antilles, Aves ridge, and Leeward Antilles. The imaged mantle structure does not allow us to discriminate between an "Intra-Americas origin" and a "Pacific origin" of the Caribbean plate.

Citation: van Benthem, S., R. Govers, W. Spakman, and R. Wortel (2013), Tectonic evolution and mantle structure of the Caribbean, J. Geophys. Res. Solid Earth, 118, 3019-3036, doi:10.1002/jgrb.50235.

\section{Introduction}

[2] In this paper, we analyze the mantle structure of the Caribbean region as imaged by the global $P$ wave velocity tomography model UU-P07 (the P06 model in Amaru [2007]) (1) to test published tectonic reconstructions for the Caribbean region and (2) to address a number of complexities that arise from incomplete spatial and temporal coverage of data underlying the tectonic reconstructions.

[3] At present, the Caribbean plate (Figure 1) is an actively deforming region between two major subduction zones: the

Additional supporting information may be found in the online version of this article.

${ }^{1}$ Department of Earth Sciences, Utrecht University, Utrecht, Netherlands.

Corresponding author: R. Govers, Department of Earth Sciences, Utrecht University, Budapestlaan 4, Utrecht NL-3584 CD, Netherlands. (r.govers@uu.nl)

(C)2013. American Geophysical Union. All Rights Reserved 2169-9313/13/10.1002/jgrb.50235
Lesser Antilles subduction in the east and the Central America subduction zone in the west. The northern boundary with the North America plate and the southern boundary with the South America plate are characterized by large strike-slip fault systems, although on a smaller scale also convergence takes place [Molnar and Sykes, 1969]. While consensus seems to exist about the first-order characteristics of the Cenozoic tectonic evolution of the Caribbean region, the Cretaceous tectonic evolution is still under debate. In Figure 2, we illustrate this with a compilation of representative tectonic reconstructions for the Caribbean plate. We use this integrated reconstruction as a guideline in our comparison of the individual reconstructions with the tomographic model. Paleo-positions of tectonic blocks and motion of surrounding continents are based on the reconstruction of Müller et al. [1999], which is a summary of several earlier studies [Pindell et al., 1988; Ross and Scotese, 1988]. To the reconstructed block positions, we added the location and nature of regional plate boundaries (with an emphasis on subduction) as presented in other studies [Escalona and 


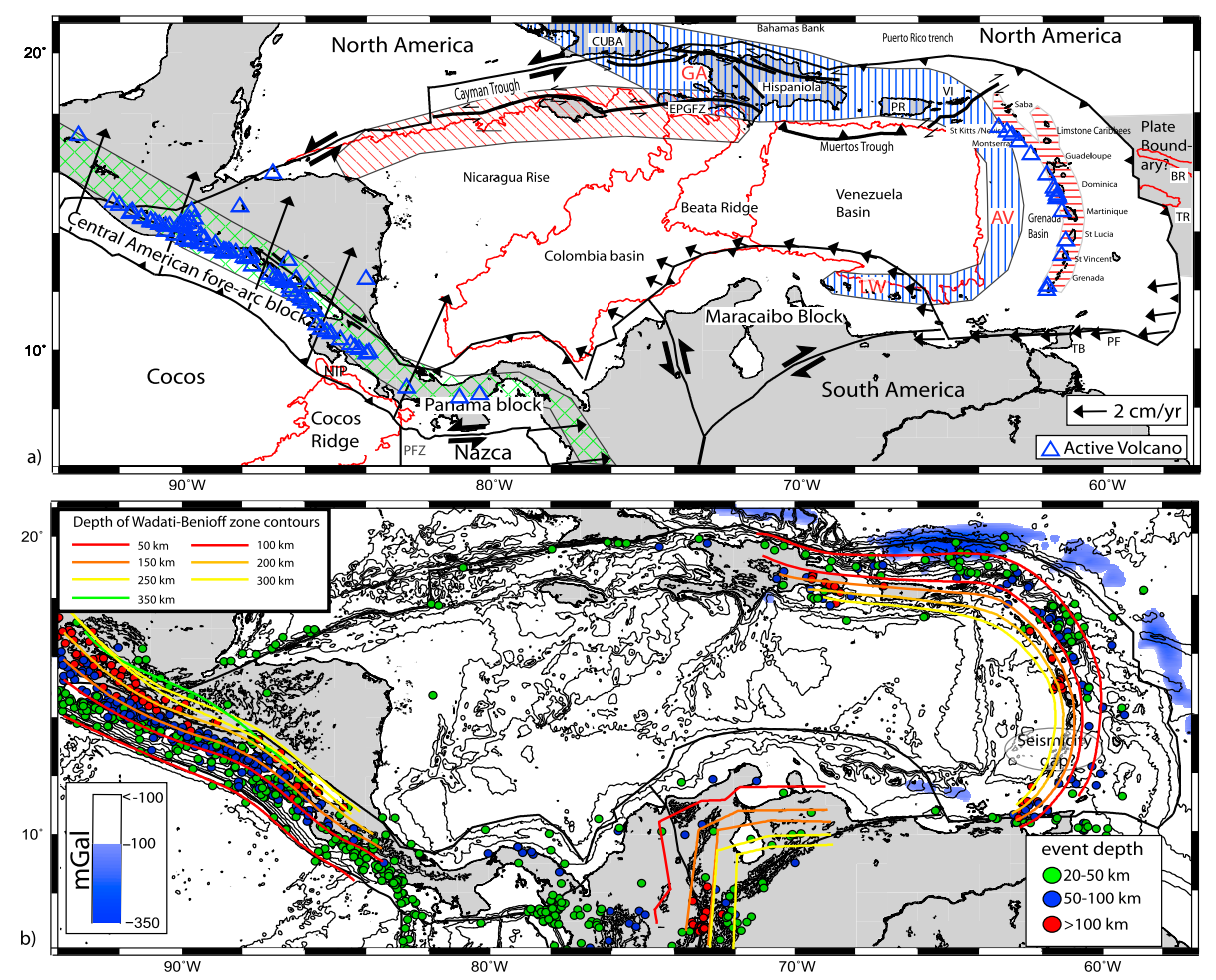

Figure 1. (a) Geography and present-day tectonics of the Caribbean plate. Bold black lines denote plate boundaries and major faults. Red lines denote major topographic provinces. Locations of island arc volcanism are shown by blue triangles. Black arrows indicate GPS-derived plate motions of surrounding plates with respect to the Caribbean plate [DeMets, 2001; DeMets et al., 2000; Kellog and Vega, 1995; Trenkamp et al., 2002; Weber et al., 2001]. The gray region east of the Lesser Antilles trench denotes the region where the plate boundary between the South and North America plates has been suggested to be located. Striped areas denote present-day positions of (extinct) volcanic arcs mentioned in the text; diagonal red stripes: Nicaragua Rise volcanic arc; horizontal red stripes: Lesser Antilles; vertical blue stripes: Great Arc of the Caribbean, consisting of the Greater Antilles (GA), Aves Ridge (AV), and Leeward Antilles (LW). BR: Barracuda Rise; EPGFZ: Enriquillo-Plantain-Garden Fault Zone; NIP: Nicoya Peninsula; PFZ: Panama Fracture zone; PF: El Pilar Fault zone; PR: Puerto Rico; TB: Trinidad and Tobago; TR: Tiburon Rise; VI: Virgin Islands. (b) Regional seismicity and gravity anomalies. Dots denote subcrustal (deeper than $20 \mathrm{~km}$ ) seismicity, where color denotes hypocenter depth. The colored lines ranging from brown to green show contour lines of the Wadati-Benioff zones [Gudmundsson and Sambridge, 1998]. Blue contours highlight the most significant free air gravity anomalies. Values $<-100 \mathrm{mGal}$ are blue, while values $>-100 \mathrm{mGal}$ are transparent.

Mann, 2011; Meschede and Frisch, 1998; Pindell and Barrett, 1990; Pindell and Kennan, 2009], and we listed the references for the critical observations underlying the reconstructions. If a particular plate boundary type is a specific feature of one of the reconstructions, we indicated this in the text balloons of Figure 2.

[4] As Figures 2a and 2b illustrate, a Caribbean plate as such did not yet exist in the Early Mesozoic when the region at the longitudes of the future Caribbean plate was subject to NW-SE directed oceanic spreading in the (western) Atlantic Ocean. Most tectonic reconstructions show Early Cretaceous subduction of Farallon lithosphere along the western margins of the North and South America plates, whereas the North America and South America plates had started drifting apart since the Late Jurassic (appropriate references can be found in Pindell and Barrett [1990]). Two scenarios have been proposed for the Middle-Late Cretaceous origin of the Caribbean plate. In the first scenario, the Caribbean plate originated within the Farallon plate, i.e., to the west of the Farallon subduction zone [Pindell and Barrett, 1990] (Figures 2a and 2c). This "Pacific origin" scenario requires a temporary halt of Farallon subduction so that the Caribbean plate can end up in an overriding plate position relative to the Farallon plate. In the second scenario, the Caribbean plate originated between the North and South America continents, east of the Farallon subduction zone [James, 2009; Meschede and Frisch, 1998] (Figures 2b and 2d). This scenario is commonly referred to as the "IntraAmericas origin" scenario. Below, in section 3.6, we discuss subduction of the Farallon plate, and subduction at the Great arc of the Caribbean and how they are expressed in our tomographic results of the lower mantle. Below, we present a more detailed account of these two tectonic scenarios.

[5] Both scenarios for the tectonic evolution converge from the Late Cretaceous onward and place Caribbean lithosphere between the North and South America continents (Figures $2 \mathrm{e}-2 \mathrm{~h}$ ), bounded by the east dipping Farallon subduction zone to the west and the west-southwest dipping 

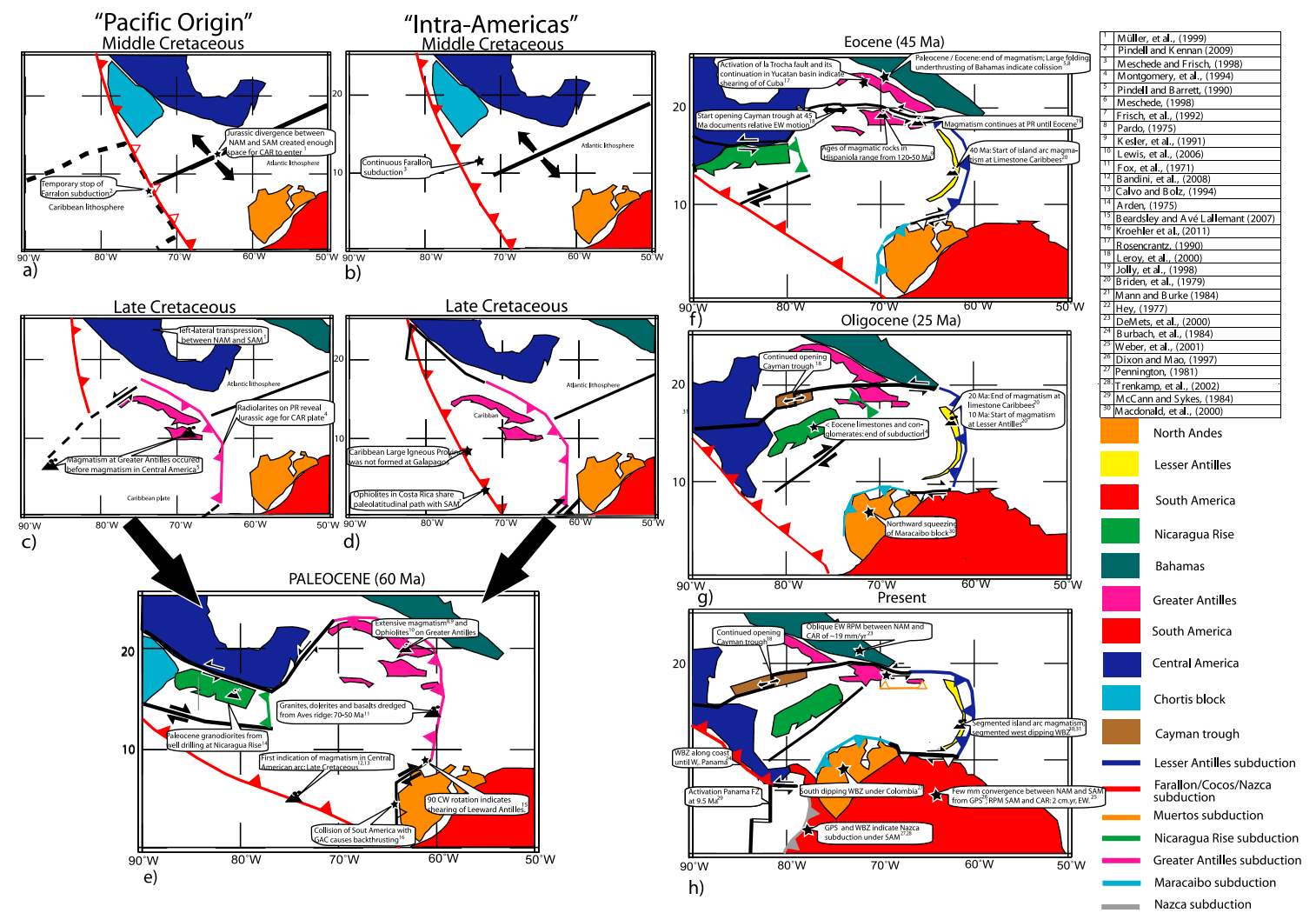

Figure 2. Schematic tectonic evolution of the Caribbean plate. Text balloons refer to critically relevant geological data and interpretations. The reconstructed positions of the different blocks in the Cenozoic are based on Müller et al. [1999]. Solid and dashed lines represent plate boundaries that are inferred from the literature, dashed plate boundaries being more interpretative. The tectonic reconstruction represents (a) the Pacific origin and (b) the "intra-Americas scenario" in the Early/Middle Cretaceous. (c-h) Subsequent tectonic reconstruction. See text for details.

Great arc of the Caribbean subduction zone to the east. Subduction of the Farallon plate continued until its Miocene fragmentation into the Nazca and Cocos plates [Hey, 1977; Lonsdale, 2005], which led to a bifurcation of subduction beneath the western margins of the Caribbean and South America plates. Miocene-present spreading between the Nazca and Cocos plates resulted in a slab window under Panama [Hey, 1977]. In section 3, we return to these reconstructions in greater detail when we evaluate their imprint on the mantle structure.

[6] At the (north) eastern boundary of the Caribbean plate, Atlantic lithosphere subducted at the Great arc of the Caribbean from the Late Cretaceous until the Eocene. In the Eocene, the Bahamas Carbonate Platform collided with Cuba and choked the northern segment of the Great Arc of the Caribbean subduction zone [Mann et al., 1995; van Hinsbergen et al., 2009]. West dipping subduction was initiated, or continued, at the Lesser Antilles arc and continued until present (Figures $2 \mathrm{f}-2 \mathrm{~h}$ ). The southern edge of the arc migrated eastward relative to the South America continent, resulting in diachronous oblique collision [Escalona and Mann, 2011]. Relative motion between South America and the Caribbean plates also resulted in Oligocene-Present subduction under northern South America [Pennington, 1981; Van der Hilst and Mann, 1994] (Figures 2g and 2h). We further elaborate on the reconstructions of the subduction at the Lesser
Antilles and under northern South America in sections 3.2 and 3.4 , respectively.

[7] The above description covers the large-scale and reasonably well-constrained features of the tectonic reconstructions. However, some of the smaller-scale subduction systems are less well constrained. Examples of proposed smaller-scale subduction are Oligocene subduction at the northwest Nicaragua Rise [Müller et al., 1999; Sykes et al., 1982] and under Puerto Rico [Molnar and Sykes, 1969; Sykes et al., 1982], Cenozoic subduction or back thrusting along the South Caribbean margin [Kroehler et al., 2011], and subduction [Byrne et al., 1985] or back-thrusting [Mann et al., 2002] at the Muertos Trough. Seismic tomography provides insight in the seismic velocity structure of the mantle and thus in the locations of subducted slabs. Therefore, we can use the tomographic model UU-P07 as an independent tool for constraining or confirming the proposed sites of convergence mentioned above. The tomographic model furthermore allows us to focus on the following pertinent aspects of the tectonic reconstructions. (1) Various tectonic scenarios exist for the present geometry, nature, and origin of subducted slabs along the northeast Caribbean plate [Calais et al., 1992; Dillon et al., 1996; Dolan et al., 1998]. The tomographic model UU-P07 contains information on the structure of these subducted slabs, and comparing it with tectonic reconstructions, seismicity, and kinematic data allows to retrace the nature and origin 
of the subducted slabs. (2) The location of the plate boundary between the North and South America plates is unknown. At the Lesser Antilles trench, the location of the plate boundary has been proposed at either $13.5^{\circ} \mathrm{N}$ [Wadge and Shepherd, 1984], $14^{\circ} \mathrm{N}-17^{\circ} \mathrm{N}$ [Müller and Smith, 1993; Pichot et al., 2012], or $19^{\circ} \mathrm{N}$ [Bird, 2003]. The plate boundary subducts at the Lesser Antilles trench and might leave its imprint on the mantle structure imaged by the tomography. (3) The suggested amount of subduction at the Mesozoic-Eocene Great Arc of the Caribbean subduction zone, which is related to the question of the origin of the Caribbean plate, ranges from hundreds of kilometers [James, 2009], $\sim 1000 \mathrm{~km}$ [Meschede and Frisch, 1998] to $3000 \mathrm{~km}$ [Pindell and Kennan, 2009]. Tomography gives insight in the amount of subducted material and therefore in the origin of the Caribbean plate.

\section{Mantle Structure Under the Caribbean Region}

\subsection{The Tomographic Model and Resolution}

[8] The global tomography model UU-P07 is derived from $\sim 18$ million $P$ wave travel-time data of global and regional earthquakes, selected from an updated version of the Engdahl et al. [1998] data set. In the PhD thesis of Amaru [2007], the tomography model was called P06. The model was subsequently labeled as UU-P07 in several papers in the open scientific literature. The lower mantle part of the model was extensively presented by van der Meer et al. [2010]. The model parameterization consists of cells (blocks) of variable dimension depending on local ray density [Bijwaard et al., 1998; Spakman and Bijwaard, 2001]. The tomographic inversion solves jointly for seismic $P$ wave velocity anomalies, event corrections, and station statics, all with respect to the 1-D reference model ak135 [Kennett et al., 1995]. Local spatial resolution is assessed with various inversion tests with synthetic velocity anomaly models. An example is presented in Figure 3 where the color-coding shows how synthetic anomalies of variable dimension and with alternating velocity amplitudes of $\pm 5 \%$ are recovered in the tomographic inversion. These positive and negative input anomalies are separated by $0 \%$ anomalies, which facilitates anomaly smearing to become visible. An extensive display of such tests for spatial resolution is presented in supporting information Figure S1. Anomaly amplitudes are generally underestimated, and smearing effects illustrate limited resolution particularly in the Atlantic and Pacific domains. We estimate that $P$ wave velocity anomalies of a horizontal scale $>150-200 \mathrm{~km}$ are detectable in most of the upper mantle near subduction regions. In the lower mantle of the Caribbean region, length scales of $200-300 \mathrm{~km}$ or larger are well detectable, although with reduced amplitudes. Here we focus on images of slabs which are sufficiently well resolved for our (relatively large-scale) interpretation purpose. Where needed, we will further address the local resolution. Examples of horizontal cross sections of the imaged mantle under the Caribbean region are shown in Figure 4 and discussed below. Figure 5 shows east-west and northsouth directed vertical cross sections through the Lesser Antilles $(L A)$ and Great Arc of the Caribbean $(G A C)$ anomalies. To illustrate the 3-D structure completely and to substantiate our interpretations of mantle structure, a movie created from depth slices is included in the supporting information.

\subsection{Connecting Tectonic Evolution With Mantle Structure}

[9] Tectonic reconstructions are generally based on geological and near-surface geophysical data and independent of data on present-day mantle structure. Testing tectonic reconstructions with imaged mantle structure relies on the strong correlation between positive velocity anomalies and subducted slabs [de Jonge et al., 1994; Hafkenscheid et al., 2006; Richards and Engebretson, 1992]. This correlation results predominantly from the temperature contrast between cold slab and warmer ambient mantle, as the effects of the compositional contrast between slab and mantle are small, at least in the upper mantle [Cammarano et al., 2003]. In the lower mantle, the cause of imaged positive anomalies is less certain, but here we also assume that positive anomalies are caused by subduction remnants, in line with the observation of anomaly continuity with imaged slab anomalies in the upper mantle and with the high correlation of positive anomalies in the lower mantle with paleo-subduction zones of the past $\sim 300 \mathrm{Myr}$ [van der Meer et al., 2010].

[10] Whereas in the upper mantle imaged slabs generally exhibit a more planar morphology, upon entering the lower mantle, the slab descent slows down and the slab thickens and becomes more amorphous [Bijwaard et al., 1998; van der Hilst et al., 1997]. Laboratory [Becker et al., 1999], numerical modeling [Gaherty and Hager, 1994], and observational studies [Hafkenscheid et al., 2006] confirm significant deformation of subducting slabs at the upper-lower mantle boundary. Gaherty and Hager [1994] suggest that slabs slow down and thicken by a factor of 2-3 upon entrance into the lower mantle (at a depth of $660 \mathrm{~km}$ ), and Hafkenscheid et al. [2006] corroborate this by comparing seismic tomography with tectonic reconstructions for the Tethyan region and obtain best results with a thickening factor of 3. In our calculations of subducted slab lengths, we use a lower limit of 2 and an upper limit of 3 for the thickening factor. We assume that there is no slab thickening in the upper mantle.

\subsection{An Overview of Imaged Slabs}

[11] Figure 4 and the movie in the supporting information show positive velocity anomalies in the upper mantle beneath the Lesser Antilles island arc, Virgin Islands, Puerto Rico, and Hispaniola. A positive anomaly, labeled $s L A$, is associated with southern Lesser Antilles subduction and is imaged to the northwest of Trinidad below a depth of $100 \mathrm{~km}$. Between 200 and $550 \mathrm{~km}$ depth, this anomaly takes the form of a west to northwest dipping slab. Shallower than $450 \mathrm{~km}$, it is separated by a low-velocity anomaly from the (positive) $n L A$ anomaly, which represents the northern Lesser Antilles slab. The nLA anomaly curves along the northeastern plate boundary, changing dip from southwest to south. Its westernmost edge is located under Hispaniola. In the transition zone, the sLA and nLA anomalies merge into a single anomaly (LA) which extends $\sim 300-400 \mathrm{~km}$ to the west in the top of the lower mantle. In the lower mantle below $800 \mathrm{~km}$, we find positive anomalies under Hispaniola and northern South America, which we will relate to Cretaceous Great Arc of the Caribbean subduction and are labeled as $n G A C$ (northern Greater Arc of the Caribbean) 

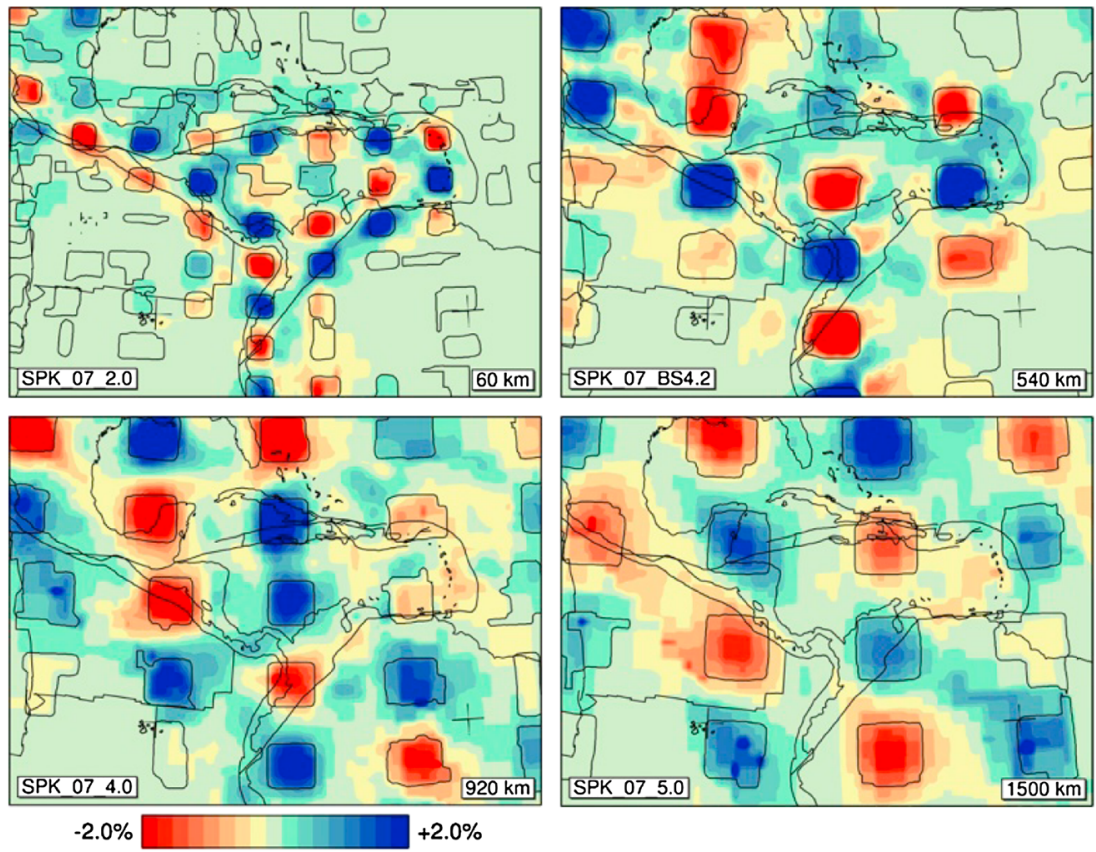

Figure 3. Typical sensitivity test results for assessing spatial resolution of the tomographic model for selected depths and synthetic test models. These test models are all global models. A more extensive description of test results is given in the supporting information (Figure S1). Black lines show coastlines and the location of isolated synthetic blocks with seismic seismic velocity anomaly amplitudes of $+5 \%$ or $-5 \%$ with respect to the 1-D reference model ak135 of Kennett et al. [1995]. Between these blocks, the synthetic anomaly is $0 \%$. These input blocks can have an irregular shape, which is due to the parameterization of the tomographic model with cells of variable dimension, which also is the reason for the absence of synthetic blocks of a particular size in some parts of the model. The colors show how the "tomographic filter" detects the synthetic blocks. This filter is the same as when the real data are on input. Comparison of "input" and "output" model leads to qualitative assessment of spatial resolution. Lack of resolution can be detected where large amplitudes occur between the blocks where block anomalies smear into the model or when block anomalies are not recovered at all. The recovery of the location of the input synthetics is spatially strongly variable, and amplitudes are systematically underestimated, which is typical for this type of global travel-time inversions. The four panels illustrate results at different depths and for different input block models. The last number in the model-label at the lower left of each panel gives the characteristic lateral spatial dimension of the input blocks in degrees, i.e., $2.4^{\circ}, 4.2^{\circ}, 4.0^{\circ}$, and $5.0^{\circ}$. The thickness of the blocks is usually half of this size. Note that a lateral distance of $5.0^{\circ}$ at $1500 \mathrm{~km}$ depth (e.g., last panel) corresponds to $\sim 400 \mathrm{~km}$. We refer to section 2.1 for further information on sensitivity analysis.

and $s G A C$ (southern Great Arc of the Caribbean). The sGAC anomaly is visible as an isolated anomaly until $\sim 1100 \mathrm{~km}$ depth, below which it is directly adjacent to the Far (Farallon) anomaly. The sGAC anomaly appears to consist of two high-velocity blobs separated by reduced amplitudes. The southern part of sGAC cannot be distinguished from the Far anomaly below $\sim 1200 \mathrm{~km}$, while the northern part remains visible to depths of $1500-1600 \mathrm{~km}$, albeit with small amplitudes. Detection of both the nGAC and sGAC anomalies is supported by the sensitivity tests for spatial resolution which show that mantle anomalies wider than $\sim 400 \mathrm{~km}$ are detectable below $1000 \mathrm{~km}$ depth, albeit with strongly reduced amplitudes (supporting information Figure S1). In the upper mantle under the Muertos Trough, a small anomaly is imaged until $\sim 100 \mathrm{~km}$ depth $(M u)$. Beneath the Maracaibo block of northern South America, a positive anomaly $(S C)$ is located in the upper mantle and attributed to S-SE-ward subduction of the Caribbean plate [Van der Hilst and Mann, 1994].
Positive seismic velocity anomalies imaged under central and northern South America correspond to subducted Cocos $(\mathrm{Co})$, Nazca $(\mathrm{Nz})$, and Farallon (Far) lithosphere, respectively. Fragments of the Cocos slab are intermittently imaged in the upper $300 \mathrm{~km}$, where seismicity indicates that a subducting slab is present. The tomographically imaged Co anomaly appears uninterrupted in the deeper upper mantle. Under Panama, a positive velocity anomaly is absent to a depth of $\sim 800 \mathrm{~km}$. Below $800 \mathrm{~km}$, the Co and $\mathrm{Nz}$ anomalies merge into an irregular positive velocity anomaly pattern, oriented parallel to the Middle America trench, which we interpreted as the Far anomaly, derived from subduction of Farallon lithosphere. The irregular makeup of the Far anomaly is within model resolution (supporting information Figure S1) and reflects a fragmented slab at depth. This will not be further considered here. The upper mantle anomalies under the Lesser Antilles, Puerto Rico and Hispaniola, northern South America, and Central America were also imaged by van der Hilst [1990]. 

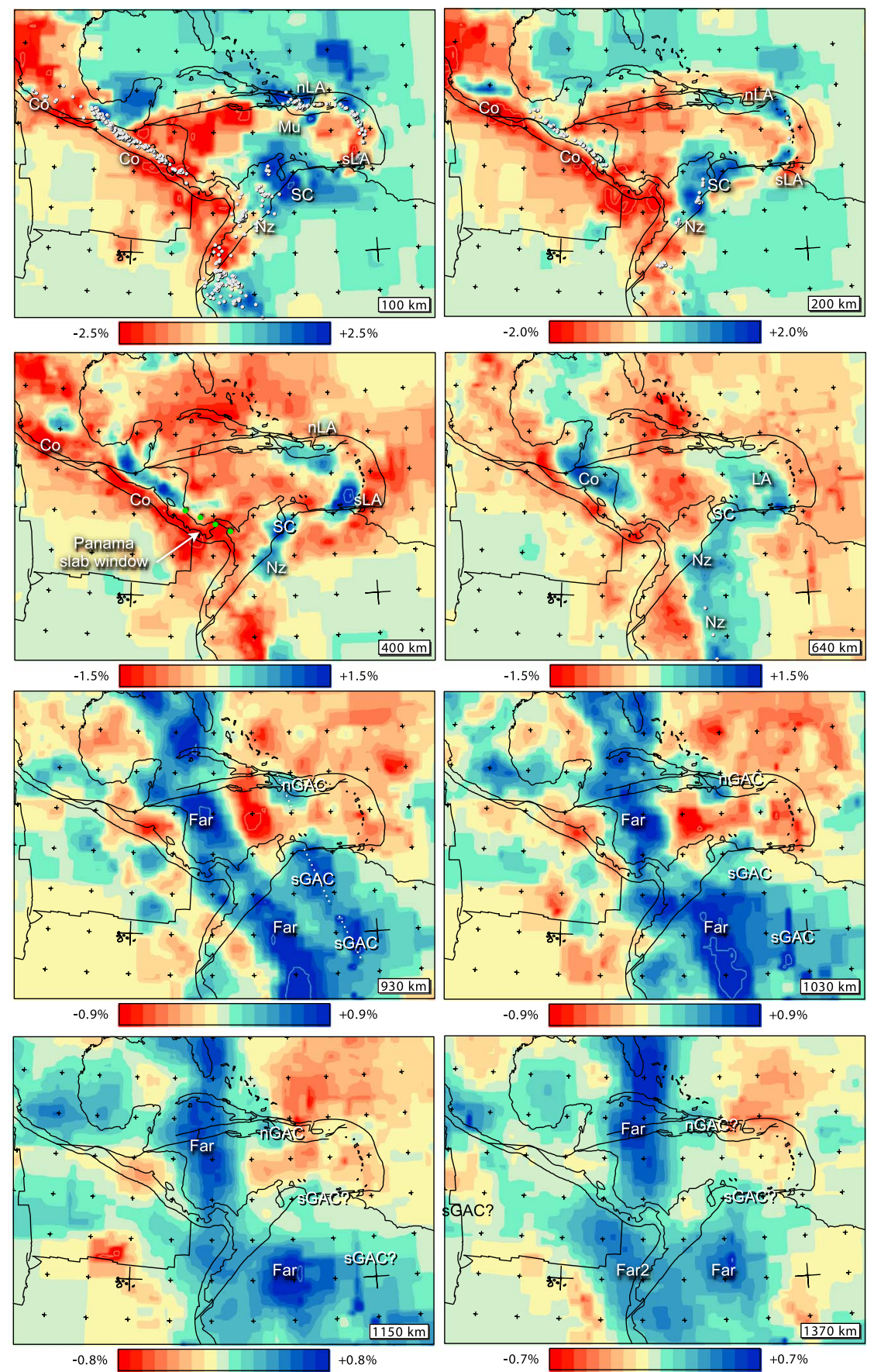

Figure 4. Tomographic slices through model UU-P07 at selected depths. Colors indicate the $P$ wave seismic velocity anomalies relative to the radial reference model ak135 of Kennett et al. [1995]. Notice that the limits of the seismic velocity anomaly scale change with depth. This depth variation follows the scaling between temperature and seismic velocity anomalies as used in Goes et al. [2004]. Blue and red colors correspond to respectively positive and negative seismic velocity anomalies. Extra contour lines indicate regions where anomalies are in excess of the color contour limits by multiples of $1 \%$. The eight panels shown are representative of the variation of mantle structure of the region and are snapshots taken from a movie presented as supporting information covering the top $1600 \mathrm{~km}$ of the mantle. We refer to this movie for studying the detail of structural variations. Labels placed either adjacent or on top of positive (blue) anomalies refer to our interpretation of imaged subduction systems: $\mathrm{Co}=\mathrm{Cocos}$; Far, Far2 =Farallon; $\mathrm{nLA}=$ northern Lesser Antilles; sLA $=$ southern Lesser Antilles; $\mathrm{SC}=$ South Caribbean; $\mathrm{Mu}=$ Muertos; $\mathrm{nGAC}=$ northern Great Arc of the Caribbean; $\mathrm{sGAC}=$ southern Great Arc of the Caribbean; $\mathrm{Nz}=$ Nazca. In the " $400 \mathrm{~km}$ " panel, we also indicated the location and width of Panama slab window. Small crosses denote the longitude-latitude grid at $5^{\circ}$ intervals. The white dotted lines in the " $930 \mathrm{~km}$ " panel indicate estimates of the lateral extent of the GAC anomalies, summing to $\sim 2000 \mathrm{~km}$. Solid lines indicate coastlines, plate boundaries or other major tectonic lineaments in the region. 


\section{Comparing Tectonic Reconstructions With Imaged Mantle Structure}

\subsection{Overall Constraints on Tectonic Reconstructions}

[12] The near absence of oceanic magnetic anomalies complicates the task of reconstructing relative motions between the Caribbean and neighboring plates. Magnetic anomalies have been identified only in the Cayman Trough and date from the Eocene to the present [Leroy et al., 2000]. Together with preceding extension, they record relative plate motion between the Caribbean and North America plates. Any older magnetic anomalies were obscured by Late Cretaceous flood basalts [Hörnle et al., 2004]. A starting point for any pre-Eocene tectonic reconstruction of the Caribbean plate is then derived from the paleo-motions/positions of the surrounding tectonic plates, in particular the relative plate motion between the North and South America plates. The amount of oceanic lithosphere, derived from spreading between these two plates, constrains the size of the future Caribbean plate. Figure 2 shows the relative location of the landmasses belonging to the two plates, together with Cretaceous to present stages of the tectonic evolution of the Caribbean domain, and with the most critical observational constraints indicated. The reconstruction is presented in the Indo-Atlantic hotspot reference frame [Müller et al., 1999], which is a mantle, or absolute motion, reference frame. Relative motion between the North and South America plates first occurred in the Cretaceous by left lateral transtension at a rate of $3-5 \mathrm{~mm} / \mathrm{yr}$ (Figures 2a-2e). Since the Paleocene (Figures 2e-2h), North America-South America motion had a (north-south) convergent component, with higher rates in the west than in the east. At $65^{\circ} \mathrm{W}$, the present-day longitude of Puerto Rico, the total Cenozoic convergence amounts to $200 \pm 94 \mathrm{~km}$. Further west, at $85^{\circ} \mathrm{W}$, the total convergence has been $445 \pm 117 \mathrm{~km}$ [Müller et al., 1999]. In the following sections, we first discuss the imaged high-velocity anomalies in the eastern part of the Caribbean region from shallow to deep, i.e., from recent to older subduction, followed by an analysis of lower mantle anomalies, and ending with recent subduction along the western margin of the Caribbean plate.

\subsection{Lesser Antilles}

[13] Subduction at the Lesser Antilles trench followed earlier subduction at the Mesozoic-Paleocene Great Arc of the Caribbean (Figures $2 \mathrm{f}-2 \mathrm{~h}$ ). Arc magmatic rocks at the Lesser Antilles date from the Eocene to present [Briden et al., 1979; Aitken et al., 2011]. The Lesser Antilles accommodated convergence between the Caribbean and the North America plates (northern part of the Lesser Antilles) and the Caribbean and the South America plates (southern part of the Lesser Antilles). The $1100 \mathrm{~km}$ east-west extent of the Cayman Trough [Leroy et al., 2000; Rogers et al., 2007], a pull-apart basin on the Eocene-present strike-slip boundary between the Caribbean and North America plates, puts a limit on the total Caribbean-North America displacement since the Eocene and thus constrains the amount of subduction at the northern Lesser Antilles to at least $1100 \mathrm{~km}$. This is a lower limit because unquantified or unmapped deformation is not included. Since relative east-west displacement between North and South America since the Eocene has been small at the longitude of the Lesser Antilles trench [Müller et al., 1999], $1100 \mathrm{~km}$ South America lithosphere must also have subducted at the southern Lesser Antilles trench. The imaged anomalies under the Lesser Antilles arc and central Caribbean extend to $\sim 1500 \mathrm{~km}$ depth (Figure 4), for which we distinguish two major anomalies, above and below $800 \mathrm{~km}$ depth. We attribute positive anomalies (sLA and nLA) from the surface to $\sim 800 \mathrm{~km}$ depth, including the flat-lying portion, with a total length of $1150 \pm 150 \mathrm{~km}$ (Figure 5a), to post-Eocene subduction at the Lesser Antilles trench. The anomalies under $800 \mathrm{~km}$ (sGAC and nGAC) we attribute to the Cretaceous subduction history of the Great Arc of the Caribbean slab. These interpretations will be made in the following sections.

\subsubsection{Southern Edge of the Lesser Antilles} Subduction Zone

[14] The sLA anomaly does not extend south of the South America-Caribbean plate boundary (the El Pilar Fault) and shows a clear slab edge which seems slightly overridden by the South America plate and which was also found in earlier global tomography models [Bijwaard et al., 1998] and in regional models [Bezada et al., 2010; Miller et al., 2009; VanDecar et al., 2003]. Epicenters of deep (>100 km) seismicity in the south Lesser Antilles slab are absent south of the plate boundary, also suggesting that the El Pilar Fault is the surface expression of the subduction edge. Such a lateral edge to a subducted slab is indicative of a special type of plate boundary, where ongoing tearing of the South America lithosphere facilitates subduction at the Lesser Antilles trench (Figure 6) [Clark et al., 2008; Miller et al., 2009; Molnar and Sykes, 1969; Niu et al., 2007]. We refer to the active locus of tearing as the Subduction-Transform-EdgePropagator (STEP) [Govers and Wortel, 2005]. The depth extent of the slab edge indicates that activity of the STEP has been increasing the length of the South America-Caribbean plate boundary since its initiation at $\sim 45 \mathrm{Ma}$. Currently, active tearing associated with the STEP is probably located west of Tobago. The resulting fault zone at the surface between South America and the Caribbean plate and in the wake of the active STEP is referred to as the STEP fault. Structurally, the STEP fault is a $(\sim 100 \mathrm{~km})$ wide lithospheric shear zone accommodating transform-type motion between the surface portion of the South America and the overriding Caribbean plate. It is a lithospheric right lateral shear zone, which at the surface corresponds roughly with the El Pilar Fault and Coche Fault.

[15] Geodynamic model experiments by Baes et al. [2011] indicate that a STEP fault is a likely candidate for subduction initiation in case of (a component of) convergence normal to the STEP fault strike. Possibly the initiation of subduction at the South Caribbean Deformed Belt happened on a former STEP fault, on the southern edge of the Great Arc of the Caribbean. Escalona and Mann [2011] and Kroehler et al. [2011] find evidence for diachronous onset of thrusting along the South Caribbean Deformed Belt, which agrees with such STEP-subduction initiation scenario. The tomographic results suggest that convergence has resulted in subduction to the west of $67^{\circ} \mathrm{W}$.

[16] East of $67^{\circ} \mathrm{W}$, we find no tomographic anomaly related to subduction, which confirms the tomographic results of Bezada et al. [2010]. Figure $5 \mathrm{~d}$ is a vertical profile at $67^{\circ} \mathrm{W}$ and shows that a significant anomaly under the South American-Caribbean plate boundary is absent here. The existence of a lithospheric STEP fault is corroborated by the crustal structure along a north-south transect [Clark et al., 2008] and recent upper mantle tomography studies [Bezada et al., 2010; Miller et al., 2009]. 

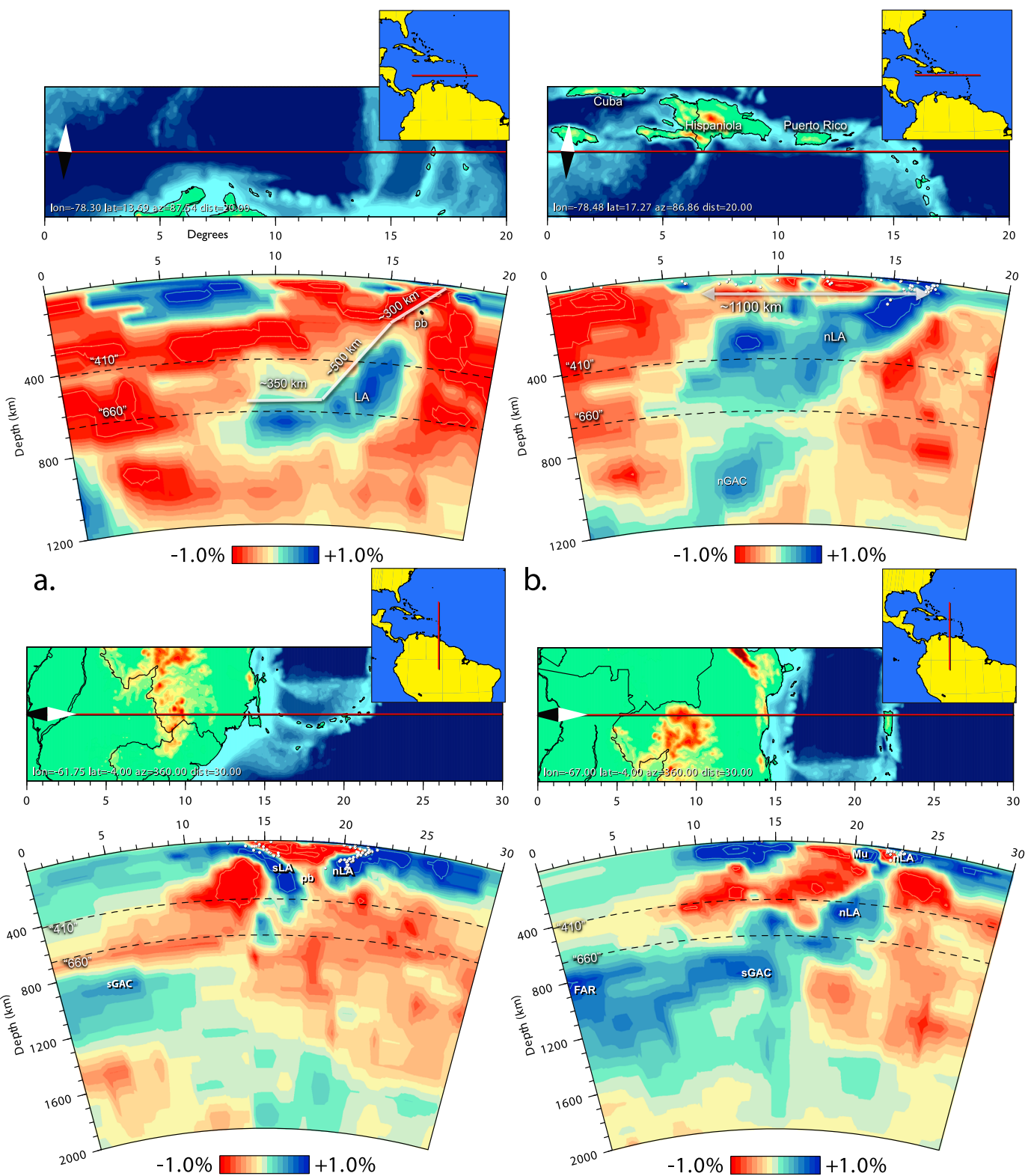

C.

d.

Figure 5. Vertical tomographic sections through (a) the central Caribbean and the central Lesser Antilles (LA) subduction zone, and (b) the northern Antilles (nLA) subduction under Hispaniola and Puerto Rico. The profiles are a great circle segment. The starting point of each section, azimuth, and arc-distance (degrees) are indicated to the lower left in the map (top panel). The tomographic section is computed along the horizontal red line, which is also plotted in the map inset showing a larger region. The compass needle (white pointing north) in the map illustrates the orientation of each section. Colors in the map denote bathymetry. The lower panel shows the tomographic section taken to a depth of $1200 \mathrm{~km}$. We refer to the caption of Figure 4 for explanation of the color-coding. White symbols indicate earthquakes from the Engdahl et al. [1998] data set. The depth of the "410" and "660" mantle seismic discontinuities is plotted with dashed lines. (a) Along the dip direction of the Lesser Antilles slab crossing the subducted plate boundary $(p b)$ between the North and South America plates. A measurement of slab length is indicated by white lines following the approximate top of the slab and amounting to $\sim 1150 \mathrm{~km}$ with an estimated uncertainty of $\sim 100 \mathrm{~km}$ on account of imperfect tomographic resolution. The lower part of the slab lies horizontal and may have sunken into the lower mantle. This agrees with the age of the subduction zone and points to a possible trench motion/jump of a few hundred kilometers to the east during the initial stage of slab subduction evolution which was incipient $\sim 45 \mathrm{Ma}$. Due to reduced resolution, a component of lateral smearing can, however, not be excluded (see supporting information Figure S1). (b) Along strike of the northern Lesser Antilles slab for which we measure about $1100 \mathrm{~km}$ with an estimated uncertainty of $\sim 100 \mathrm{~km}$. The slab edge is found under central Hispaniola. At larger depth under Hispaniola, we find the northern Greater Antilles 


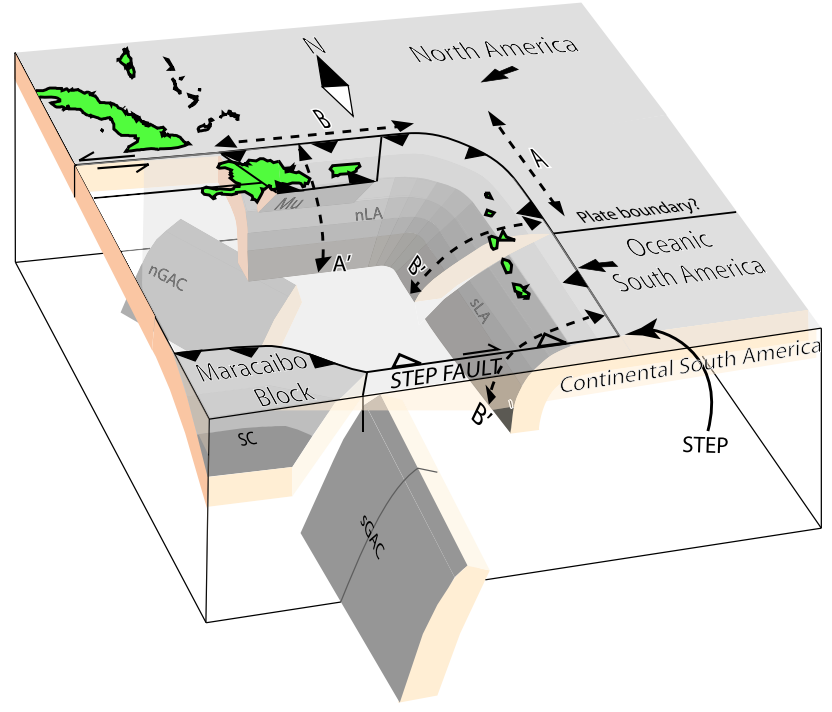

Figure 6. Schematic illustration of the mantle structure and plate boundaries in the eastern Caribbean region. The black arrows denote the plate motion relative to the Caribbean plate. Abbreviations for the different subducted slabs: sLA: southern Lesser Antilles; nLA: northern Lesser Antilles / Puerto Rico; sGAC: southern Great Arc of the Caribbean; nGAC: northern Great Arc of the Caribbean; SC: South Caribbean.

\subsubsection{Central Lesser Antilles: Plate Boundary North America-South America}

[17] A west dipping Wadati-Benioff zone extends to a depth of $\sim 300 \mathrm{~km}$ beneath the Lesser Antilles island arc [McCann and Pennington, 1990]. Under the northern Lesser Antilles, the dip angle of the Wadati-Benioff zone is $60^{\circ}$, while under the southern Lesser Antilles it ranges from $50^{\circ}$ in the north to almost vertical in the south. The different dip angles have been interpreted as evidence for two separate slab segments [Wadge and Shepherd, 1984]. A further indication for the possible slab segmentation is a seismicity gap in the Wadati-Benioff zone located at around $13^{\circ} \mathrm{N}$, under St. Vincent and the Grenadines. It extends from the surface until the end of the Wadati-Benioff zone. Finally, based on volcanic production rates and magmatic composition, MacDonald et al. [2000] divide the Lesser Antilles arc into three segments roughly coinciding with the northern Wadati-Benioff zone, the southern Wadati-Benioff zone, and the gap separating them. At present, North AmericaSouth America relative plate motion is small at the Lesser Antilles trench: $1.3 \mathrm{~mm} / \mathrm{yr}$ of oblique convergence [DeMets et al., 2010]. During the Late Cretaceous/Early Cenozoic, however, transtension resulted in $\sim 150 \mathrm{~km}$ divergence, followed by $\sim 40 \mathrm{~km}$ of convergence, which suggests the presence of a plate boundary between the North and South America plates [Müller et al., 1999]. Three east-west oriented locations have been proposed for the exact position of this enigmatic plate boundary (Figure 1a): (1) at $13.5^{\circ} \mathrm{N}$, based on the location of a vertical gap in the WadatiBenioff zone of the Lesser Antilles [Wadge and Shepherd, 1984]; (2) between $14^{\circ}$ and $17^{\circ} \mathrm{N}$, at the isostatically uncompensated Tiburón and Barracuda ridges [Müller and Smith, 1993]; and (3) around $\sim 19^{\circ} \mathrm{N}$ based on (scattered) seismicity [Bird, 2003].

[18] The UU-P07 model shows two distinct anomalies, nLA and sLA, separated by a region of low $P$ wave velocity (Figures 4 and 5a and movie in the supporting information). The anomalies are separate to a depth of $\sim 400 \mathrm{~km}$ and possibly across the entire upper mantle (Figure 5c). The low-velocity zone separating nLA and sLA is a sufficiently resolved feature of the tomographic model. This low-velocity zone is most likely an expression of the downdip continuation of the subducting North America-South America plate boundary, as further substantiated in the following section. The low-velocity anomaly is located between latitudes $13^{\circ} \mathrm{N}-15^{\circ} \mathrm{N}$ (Figures 4 and $5 \mathrm{c}$ ), which does not include the plate boundary location of Bird [2003]. It partially overlaps with the location of the Tiburón and Barracuda ridges and coincides with the vertical gap in the Wadati-Benioff zone [Wadge and Shepherd, 1984]. Along a central W-E section, we measure $1100-1200 \mathrm{~km}$ of Lesser Antilles subduction (Figure 5a). This includes the low-velocity zone in the top $400 \mathrm{~km}$ (which we interpret as the subducted plate boundary between the North and South America plates), and the flat-lying portion at the lower-upper mantle boundary. We conclude that the imaged slab length of the Lesser Antilles slab above a depth of $\sim 800 \mathrm{~km}$ agrees with the suggested $\sim 1100 \mathrm{~km}$ of Lesser Antilles subduction since $\sim 45 \mathrm{Ma}$. Corroborating earlier findings by van der Hilst and Spakman [1989], the flat-lying portion of the LA anomaly may be indicative of a few hundred kilometers of eastward trench motion during $\sim 45 \mathrm{Myr}$ of subduction. Overall, the image of Lesser Antilles subduction implies that the trench has been reasonably stationary relative to the mantle, consonant with tectonic reconstructions [Müller et al., 1999]. This inference is also in agreement with our explanation of the nLA anomaly in the next section.

\subsubsection{Northern Edge of the Lesser Antilles}

\section{Subduction Zone}

[19] The west dipping Wadati-Benioff zone under the northern Lesser Antilles turns around the corner into a south dipping Wadati-Benioff zone beneath Eastern Hispaniola, Puerto Rico, and the Virgin islands [McCann and Sykes, 1984; Molnar and Sykes, 1969; Sykes and Ewing, 1965]. The south dipping Wadati-Benioff zone, which is up to $240 \mathrm{~km}$ deep, is commonly interpreted as evidence for subducted North America lithosphere, despite the fact that active volcanism and high surface heat flow along the island arc are absent and relative plate motion along the Puerto Rico trench is highly oblique (Figure 1a). A prominent bathymetric trough and a large negative free air gravity anomaly

Figure 5. (continued) anomaly (nGAC). (c) A north-south profile, taken at $61.75^{\circ} \mathrm{W}$. It illustrates the existence of a lowvelocity anomaly, interpreted as the subducting plate boundary, between the northern Lesser Antilles anomaly and southern Lesser Antilles anomaly (sLA). (d) A north-south profile, taken at $67^{\circ} \mathrm{W}$, in the downdip direction of the northern Lesser Antilles anomaly along the north Caribbean plate boundary. It shows the opposing Muertos (Mu) slab and at depth the southern Great Arc of the Caribbean anomaly. At the southern margin of the Caribbean plate, an anomaly indicating significant subduction here is absent. There is a high-velocity anomaly until a depth of approximately $200 \mathrm{~km}$, but it cannot be distinguished from the high velocities associated with the root of the South American continent. 
(Figure 1b) are indicative of dynamic topography and thus support the interpretation that the Puerto Rico slab is attached to the North America plate at the surface.

[20] This slab is commonly interpreted as predominantly brought in by Eocene to present westward subduction at the Lesser Antilles island arc [Calais et al., 1992; McCann and Pennington, 1990; Schell and Tarr, 1978]. In contrast to the STEP scenario at the Caribbean-South America plate boundary, lithospheric tearing does not occur here, and the Puerto Rico slab remains attached to the surface part of the North America plate (Figure 5d). This results in a curved (amphitheater-like) geometry supported by tomography (Figure 4 and movie in the supporting information). Thus, we refer to the development of this geometry since the Eocene as the "amphitheater scenario." Based on the Wadati-Benioff zone, the Puerto Rico slab has a lateral edge beneath eastern Hispaniola, which is also seen in tomography (Figure 4). A consequence of this geometry is that, as the slab moves westward with North America, its western edge pushes and deforms the overriding Caribbean lithosphere. Focal mechanisms derived from shallow earthquakes $(<50 \mathrm{~km})$ indicate sinistral slip on a dipping plane [Calais et al., 1992], in agreement with this scenario, whereas deeper ( $>50 \mathrm{~km}$ depth) focal mechanisms indicate north-south compression, in agreement with the existence of a slab at depth. The lateral motion of the slab might also explain the absence of active island arc magmatism along the Puerto Rico margin, as dehydration melting already occurred earlier beneath the Lesser Antilles margin in the east [Calais et al., 1992], so that all fluids have been released by the time the particular slab segment arrives further west under Puerto Rico.

[21] The amphitheater scenario implies that the slab length along the Puerto Rico trench (length B in Figure 6) matches the amount of east-west convergence between the Caribbean and North America plates (length $\mathrm{B}^{\prime}$ in Figure 6), which is $1100 \mathrm{~km}$. This is indeed what is corroborated by the tomographic structure as illustrated in Figure 5b, where we measure $\sim 1100 \mathrm{~km}$ of along-strike subduction zone length. This is also in agreement with the downdip length of the nLA anomaly at the Lesser Antilles ( $\mathrm{B}^{\prime}$ in Figure 6) as demonstrated in Figure 5a. As the amount of convergence between North America and the Caribbean has been small during the Cenozoic and part of this convergence was accommodated by back thrusting at the Muertos trough [ten Brink et al., 2009] and South Caribbean Deformed Belt [Kroehler et al., 2011], most of the material along the Puerto Rico trench is brought in by subduction at the Lesser Antilles trench. The downdip length of the nLA anomaly at the Puerto Rico trench ( $\mathrm{A}^{\prime}$ in Figure 6) should therefore roughly coincide with the along-strike length of the northern Lesser Antilles trench (A in Figure 6). The length of the nLA anomaly along the Lesser Antilles trench (A) and the downdip length of the nLA anomaly along the Puerto Rico trench $\left(\mathrm{A}^{\prime}\right)$ are both $\sim 500-700 \mathrm{~km}$. The amphitheater scenario thus agrees with both the tectonic reconstruction and the tomographic results. Focal mechanisms deeper than $50 \mathrm{~km}$ under Hispaniola do not show EW compression as would be expected by westward motion of the western Puerto Rico slab edge. Possibly, this deformation is taken up aseismically. The observed seismicity is indicative of north-south extension associated with initiation of detachment of the Puerto Rico slab [Calais et al., 1992]. The vertical gap associated with this incipient process is possibly too small to be resolved by the tomographic results.

[22] Figure 6 summarizes our interpretation of the slab geometries beneath the east Caribbean plate showing the amphitheater in the north and the slab edge and the active STEP in the south. The difference between the northern and southern plate boundaries may be related to contrasts in lithospheric strength; STEP activity preferably takes place along a preexisting weak zone or material boundary, such as a continental margin, as is the case for the southern Lesser Antilles. Although there are various carbonate seamounts present along the northern boundary[Grindlay et al., 2005], a continental margin is absent, and Atlantic lithosphere near the Puerto Rico trench has an age of around $100 \mathrm{Myr}$ [Müller et al., 2008]. The Atlantic lithosphere is therefore very strong, and this may have prevented STEP activity along the northeast Caribbean plate boundary.

[23] The Puerto Rico slab is a geometric consequence of the absence of STEP activity along the northern boundary of the Caribbean plate. The down bending of this curved slab causes trench-parallel tensional stresses in the Lesser Antilles slab [Burbach and Frohlich, 1986; ten Brink, 2005]. Ten Brink [2005] suggested the existence of a vertical tear north of Puerto Rico, caused by trench-parallel stresses. Also, the opening of the (preexisting weakness zone) of the subducted North America-South America plate boundary may have been a consequence of these stresses. The resulting gap between the northern and southern Lesser Antilles slab fragments allowed toroidal return flow [Schellart, 2004b]. With the southern Lesser Antilles slab having two free edges (north and south) and the northern Lesser Antilles slab effectively having only one (south), the southern Lesser Antilles slab attained a steeper dip [Schellart, 2004a], as is indeed observed [Wadge and Shepherd, 1984]. The absence of STEP activity along the northern plate boundary thus could be responsible for the observed slab gap, i.e., the opening plate boundary under the central Lesser Antilles, and for variations in the dips of the northern and southern Lesser Antilles slabs.

\subsection{Muertos Subduction}

[24] Global Positioning System (GPS) measurements show that the relative plate motion between Puerto Rico and the Caribbean plate is negligible at present, $\sim 1 \mathrm{~mm} / \mathrm{yr}$ [Jansma et al., 2000]. The diffuse Wadati-Benioff zone under Puerto Rico allows an interpretation of a north dipping WadatiBenioff zone that extends from the Muertos Trough to a depth of $100 \mathrm{~km}$ (Figure 1b). The Muertos Trough has been proposed to be the southern boundary of the Puerto Rico and Hispaniola microplates [Byrne et al., 1985; Dolan et al., 1998; McCann and Pennington, 1990]. Byrne et al. [1985] and Granja Bruña et al. [2009] interpret here an accretionary wedge of unknown age. Ten Brink et al. [2009] give an alternative perspective; full-blown subduction requires that both the crust and lithospheric mantle must at least have under-thrusted beneath the entire overriding lithosphere. Based on the low angle of thrusting [Byrne et al., 1985], Ten Brink et al. [2009] argue that much more than $100 \mathrm{~km}$ of convergence is needed to arrive at subduction, and they thus conclude that the Muertos Trough is limited to the crust and stems from retro-arc thrusting. Convergence at the Muertos trough is thus either accommodated by subduction or by large-scale (back) thrusting. 


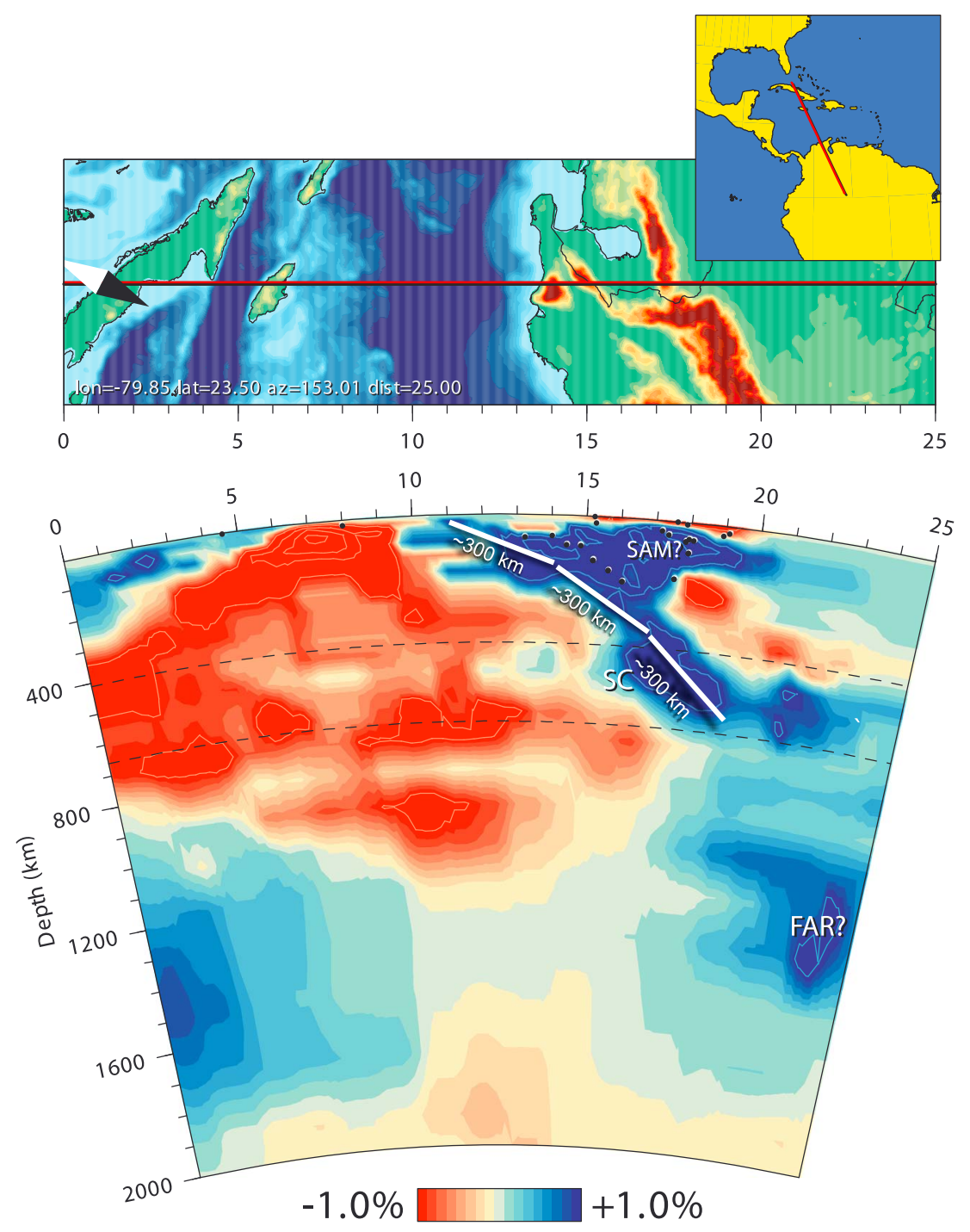

Figure 7. Tomographic section showing the South Caribbean (SC) anomaly. For figure layout, see the caption of Figure 5. We measure around $900 \mathrm{~km}$ of South Caribbean slab length. The angle of subduction is $40^{\circ}$. In the upper $400 \mathrm{~km}$, the Nazca slab is also visible. In the lower mantle, the southern Great Arc of the Caribbean anomaly and Farallon anomalies are visible.

[25] A small anomaly $(\mathrm{Mu})$ is imaged at a depth of $\sim 100 \mathrm{~km}$ (Figures 4 and 5d). The dimensions of this anomaly are at the local resolution limit of the model, but a longer slab would be detectable. The amount of under-thrusting in the Muertos Trough in the tomographic results thus appears to be just about enough to refer to it as subduction.

\subsection{South Caribbean Subduction}

[26] GPS measurements show that the Maracaibo block presently moves $14 \mathrm{~mm} \mathrm{yr}^{-1}$ to the northwest relative to the Caribbean plate [Trenkamp et al., 2002]. This, in combination with the long-term (north) westward relative motion of South America, resulted in subduction of Caribbean lithosphere under the Maracaibo block and South America leading to the South Caribbean slab (Figures $2 \mathrm{f}-2 \mathrm{~h}$ ). This subduction has been interpreted as back thrusting of earlier subduction of South American lithosphere under the Caribbean [Kroehler et al., 2011]. Subduction is suggested along most of the south Caribbean margin. The southeast dipping Wadati-Benioff zone under northeast Colombia [Pennington, 1981] is interpreted as evidence of this South Caribbean slab. The UU-P07 model shows a broad anomaly (SC) under the Maracaibo block (Figures 4 and 7). This South Caribbean anomaly has an average dip of $\sim 40^{\circ}$ to the southeast, and we interpret this as Caribbean lithosphere being overthrust by the Maracaibo block. Further to the west, Nazca lithosphere subducts eastward under the South America plate, putting the two slabs close to another and making it difficult to distinguish them. From the surface to $\sim 350 \mathrm{~km}$ depth, the tomography model shows a single anomaly, probably representing both the Nazca and South Caribbean slabs. Using a regional tomographic model of seismic attenuation and hypocenters Vargas and Mann [2013] suggest that the boundary between the two slabs is located around $5.7^{\circ}$, running roughly east-west. Below $350 \mathrm{~km}$, two separate anomalies are observed that we interpret as the separate Nazca and South Caribbean slabs. The $\mathrm{SC}$ anomaly can only be traced across the upper mantle, 
while the Nazca anomaly (Nz) continues into the lower mantle, where it merges with the Far anomaly. Relative plate motion between the Caribbean and South America plates, in combination with the northward motion of the Maracaibo block, suggests about $1000 \mathrm{~km}$ of convergence. The SC anomaly is found across the upper mantle and is at least $900 \mathrm{~km}$ long (Figure 7). The horizontal extent of the anomaly is from $76^{\circ} \mathrm{W}$ to $67^{\circ} \mathrm{W}$, indeed indicating subduction along a significant portion, but not all, of the South Caribbean margin [Kroehler et al., 2011]. East of $67^{\circ} \mathrm{W}$, the tomography supports the STEP fault scenario. The imaged Nz and SC anomalies are also imaged in earlier studies [Taboada et al., 2000; Van der Hilst and Mann, 1994], although van der Hilst and Mann [1994] did not image the connection of this anomaly with lower mantle anomalies. Figure 6 shows the South Caribbean slab, overridden by the Maracaibo block.

\subsection{Nicaragua Rise Subduction}

[27] Tectonic reconstructions show 500-700 km of EoceneOligocene convergence between the Nicaragua Rise/south Hispaniola and north Hispaniola [Müller et al., 1999; Sykes et al., 1982]. This is based on Paleocene granodiorites dredged at the Nicaragua Rise [Arden, 1975] and paleomagnetic data suggesting $8^{\circ}$ of latitudinal convergence between south and north Hispaniola [van Fossen and Channell, 1988]. Pindell and Barrett [1990] suggest that Guatemala, the Nicaragua Rise/south Hispaniola, and Jamaica formed one continuous island arc. Based on Müller et al. [1999], we thus expect a slab that is $500-700 \mathrm{~km}$ long and a few hundred kilometers wide. In contrast, Mann [2007] suggests strike slip as the main process to bring the Nicaragua Rise and South Hispaniola in place.

[28] Since in other regions slab remnants of comparable subduction age and spatial extent are predominantly found in the transition zone and /or the top of the lower mantle [e.g., Spakman and Wortel, 2004], we expect to image the "Nicaragua Rise" slab at similar depths. However, we do not find a positive wave velocity anomaly that can be attributed to the Nicaragua Rise slab. The only possible candidate, the nGAC anomaly at $\sim 800-1000 \mathrm{~km}$ depth, is discarded, since the northern edge of Nicaragua Rise anomaly should lie south of the northern edge of the Great Arc of the Caribbean slab, and the nGAC anomaly does not meet this requirement. The spatial resolution of the UU-P07 model around the $660 \mathrm{~km}$ discontinuity is around $\sim 200-300 \mathrm{~km}$ in all directions, which should suffice to detect such a slab, if existing. In view of available information, an acceptable interpretation is that the amount of Nicaragua Rise subduction was smaller, or that subduction did not occur, as suggested by the tectonic reconstruction of Mann [2007]. This interpretation is also supported by the large uncertainties in the paleomagnetic observations on which this convergence phase is based [van Fossen and Channell, 1988]. We conclude that the UU-P07 model presents no evidence for a Nicaragua Rise slab of 500-700 km length.

\subsection{Farallon and Great Arc of the Caribbean Subduction}

[29] Since the Mesozoic, the Farallon plate subducted eastward along the west coast of North America, while under South America subduction was more fragmented [Jaillard et al., 1990]. Magmatic rocks and ophiolites on Cuba, Puerto Rico, and Hispaniola provide evidence for early
Cretaceous-Paleocene convergence at the Great Arc of the Caribbean. Magmatism took place during the same time interval at the Aves Ridge and Leeward Antilles. Together, this formed the Great Arc of the Caribbean [Pindell and Barrett, 1990], where Atlantic lithosphere was consumed by southwest dipping subduction [Jolly et al., 2008] (Figures 2c-2f). The total amount of subduction is controversial as there is no consensus on the initial location and size of the Caribbean plate, which allowed for the conception of two end member scenarios for the tectonic evolution of the Caribbean region: (1) The Pacific origin scenario (Figures 2a and 2c) assumes that the Mesozoic Caribbean plate was part of the Farallon plate [Pindell and Barrett, 1990]. Upon arrival at the Farallon trench, where the Farallon lithosphere subducted eastward under South and North America, subduction regionally stopped at the Central America trench. This was either accomplished by a change to strike-slip motion along the trench [Pindell and Kennan, 2009] or a complete subduction polarity reversal [Burke, 1988]. Westward dipping subduction of North and South America lithosphere was initiated at the Great Arc of the Caribbean, and roll back (relative to the North and South America plates) transported the future Caribbean plate further to the (north) east. In the Late Cretaceous, Farallon subduction reinitiated at the Central America trench [Meschede and Frisch, 1998; Pindell and Barrett, 1990], thus separating the Caribbean plate from the Farallon plate west of the Central America trench. This scenario implies a window in the Farallon slab of at least the width and length of the Caribbean plate at that time. (2) The alternative Intra-Americas origin scenario (Figures $2 \mathrm{~b}$ and 2d) places the Mesozoic Caribbean plate east of the Farallon trench in the late Early Cretaceous [Meschede and Frisch, 1998]. The Great Arc of the Caribbean defined the northeastern boundary of the Caribbean plate, while the Farallon subduction zone defined the southwestern boundary. In this scenario, Farallon subduction has been continuous.

[30] On the southern edge of the Great Arc of the Caribbean, both scenarios require right lateral shear motion between the Caribbean plate and continental South America, together with a variable component of convergence since the Cretaceous. This is supported by observations of a $90^{\circ}$ rotation of blocks along the North Andes since the Late Cretaceous (see Beardsley and Avé Lallemant [2007] for an overview) and by the space-time progression of arc magmatism at the Leeward Antilles (Figure 2c). The two scenarios for the Mesozoic tectonic evolution lead to different amounts of subduction at the Great Arc of the Caribbean, ranging from $\sim 1000 \mathrm{~km}$ (Intra-Americas origin) to $2000-3000 \mathrm{~km}$ (Pacific origin), both with a slab width of $\sim 2000 \mathrm{~km}$.

[31] In the Paleocene, both scenarios converge. Paleocene to Eocene (soft) collision of the Great Arc of the Caribbean with the Bahamas platform (Figures 2e-2f) ended subduction near Cuba [Pindell and Barrett, 1990]. The collision of the Bahamas platform with the Great Arc of the Caribbean resulted in a change in motion from northeastward to eastward of the Caribbean plate relative to North America [Meschede and Frisch, 1998; Pindell and Barrett, 1990; Pindell and Kennan, 2009]. Continued convergence between the Caribbean plate and North and South America was accommodated along the new Lesser Antilles plate boundary (Figures $2 \mathrm{f}-2 \mathrm{~h}$ ). Several suggestions exist on how the transition of subduction at the old plate boundary at the Aves ridge 
to the new plate boundary at the Lesser Antilles took place. Either there was a complete cessation of subduction with new subduction initiated at the Lesser Antilles [Kearey, 1974], or subduction was continuous and delamination or a slab dip change caused the westward jump in subduction [Aitken et al., 2011; Bouysse, 1988].

[32] We interpret the Far (Figure 4) anomaly to be derived from Cretaceous to Miocene subduction at the Central America trench. The Far anomaly (Figure 4) is almost vertical with a NNW-SSE orientation. Above 800-900 km depth, we correlate anomalies $\mathrm{Co}$ and $\mathrm{Nz}$ with the Cocos and Nazca plates that resulted from the Farallon plate break-up at $\sim 23 \mathrm{Ma}$. This will be further discussed in the next section. In the Caribbean realm, the Far anomaly can be followed at least down to the midlower mantle. Below this depth, the Far anomaly remains clearly visible beneath North America, is weak under northwest South America, and absent south of this region [van der Meer et al., 2010].

[33] The nGAC and sGAC anomalies are interpreted to be derived from Cretaceous-Eocene subduction of North America lithosphere at the Great Arc of the Caribbean in view of the following considerations. The Lesser Antilles slab, with a length of $\sim 1100 \mathrm{~km}$, resides predominantly in the upper mantle with local extensions to $700-800 \mathrm{~km}$ depth (Figure 5a) and can be fully explained by subduction evolution since $\sim 45 \mathrm{Ma}$, as discussed before. Slightly west of the toe of the Lesser Antilles slab, the GAC anomalies are found as a downward continuation of the LA anomaly parallel to the Farallon anomaly to the west. This puts the GAC anomaly in the correct position relative to the LA anomaly. The sGAC anomaly, identified by van der Meer et al. [2010] as the "Venezuela slab," is in the correct Late Cretaceous position between the North America and South America plates and at the western boundary of the proto-Caribbean (Atlantic) basin. The nGAC anomaly is located beneath Hispaniola and directly to the north of the sGAC anomaly. The sGAC anomaly is located to the south with respect to the present-day position of the Greater Antilles islands and the Lesser Antilles subduction. This reflects the absolute northward motion of the North and South America plates, as predicted by the global tectonic reconstruction of Torsvik et al. [2008], and agrees with a total detachment of the Great Arc of the Caribbean slab during the Eocene, implying a discontinuity between Great Arc of the Caribbean subduction and subsequent Lesser Antilles subduction. The slight E-W offset between the GAC and LA anomalies also suggests a discontinuity between the Lesser Antilles and Great Arc of the Caribbean slabs, in line with cessation of the subduction at the Great Arc of the Caribbean during the Eocene [Kearey, 1974], although magmatism in Puerto Rico was continuous until the Oligocene. Alternatively, the E-W offset can be interpreted as a flat-lying slab suggesting rapid trench-roll back, with accompanying slab steepening causing the eastward jump in subduction [Aitken et al., 2011].

[34] The division of the GAC anomaly into a northern and southern segment by a low-velocity zone is not a common feature of existing tectonic reconstructions but is a resolved feature on account of various resolution tests (supporting information Figure S1). One possible explanation may be that the Proto-Caribbean ridge that separated the North and South America plates subducted at the Great Arc of the Caribbean [Pindell et al., 2006] resulting in a separation of the anomalies during subduction. If this were the case, we would expect the low-velocity anomaly to be more central in the entire GAC anomaly. An alternative location for the Proto-Caribbean ridge is the zone of reduced anomaly amplitudes separating the sGAC anomaly in two parts. A possible explanation for the low-velocity zone between the nGAC and sGAC anomalies may then be a (early?) bifurcation in the Great Arc of the Caribbean subduction system where a smaller northern segment, carrying Cuba and Hispaniola, ruptured away from the larger southern segment. A similar bifurcation of a subducting basin leading to a large separation between slabs at depth has been proposed to explain both the tectonic evolution [Lonergan and White, 1997] and upper mantle structure [Spakman and Wortel, 2004] of the Western Mediterranean. Based on this interpretation, we estimate the original N-S extent of the Great Arc of the Caribbean would have been $2000 \pm 450 \mathrm{~km}$, which is in agreement with the tectonic reconstructions. The estimate is the summed length of the nGAC and of the two sGAC anomaly fragments as indicated by the white dotted lines in Figure 4 at $930 \mathrm{~km}$. The $450 \mathrm{~km}$ error is estimated by assuming a $150 \mathrm{~km}$ imaging uncertainty on each of the six endpoints of the three dotted segments.

[35] The GAC anomalies can be followed to about $1500 \mathrm{~km}$ depth, although with strongly reduced amplitudes below $1200 \mathrm{~km}$ depth. If we take $1200 \mathrm{~km}$ as the downdip end of the northern Great Arc of the Caribbean slab and the updip end at $800 \mathrm{~km}$ depth, this corresponds to $\sim 800$ to $\sim 1200 \mathrm{~km}$ (slab thickening factor of 2 or 3 , respectively) subduction at the Great Arc of the Caribbean. If $1500 \mathrm{~km}$ is taken as the downdip end, we infer 1400 to $2100 \mathrm{~km}$ (slab thickening factor of 2 or 3 , respectively) of subduction. These inferences lead to a slab length prediction in between the Intra-Americas origin and Pacific origin scenarios for the Caribbean plate. However, the large amount of subducted material in the upper and lower mantle under the Lesser Antilles trench excludes the tectonic reconstruction of James [2009], who suggested that the amount of relative motion between the Caribbean and North or South America plates was in the order of a few hundreds of kilometers.

[36] The fact that the Farallon slab is found adjacent to the sGAC and nGAC anomalies may suggest that a slab window in the Farallon slab is not present at the time of Great Arc of the Caribbean subduction. However, the subduction velocity of the Farallon slab may have been much larger than the sinking velocity of the relatively small (detached) Great Arc of the Caribbean slab in which case a window in the Far anomaly should be searched for at larger depths. Mantle structure below $\sim 1000 \mathrm{~km}$ under northwest South America shows that the southern segment of the Far anomaly is fragmented with one large anomaly located more to the west (Far2 in Figure 4 and movie in the supporting information). Although a slab window could be interpreted east of that anomaly, it seems to be located too far north with respect to the location of the sGAC anomaly and not wide enough. From our analysis of mantle structure, no equivocal conclusion can be reached to discriminate between the alternative tectonic scenarios.

\subsection{Cocos Subduction and the Panama Slab Window}

[37] Subduction of Farallon lithosphere along the Central America trench continued until the Oligocene-Miocene boundary (23 Ma, Figure $2 \mathrm{~g}$ ), when the Farallon plate broke 


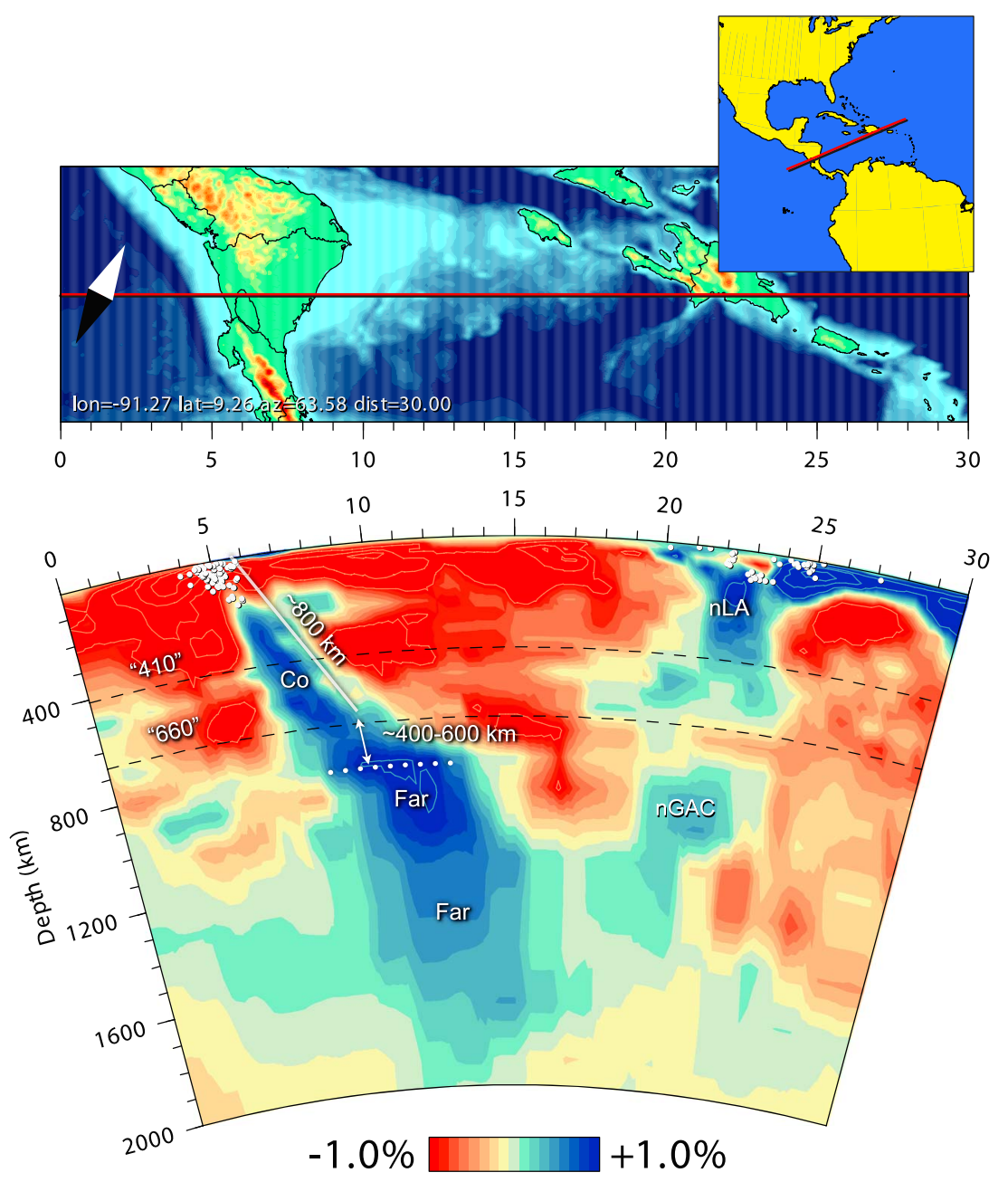

Figure 8. A tomographic section showing the Cocos (Co) and Farallon (Far) slabs. For figure layout, see the caption of Figure 5. We measure between 1100 and $1300 \mathrm{~km}$ of Cocos slab length depending on slab thickening factor $(2$ or 3 ) for the lower mantle. With negligible thickening, the Cocos slab has a length between 900 and $1000 \mathrm{~km}$. Below the dotted line (between 800-900 km), we find the Farallon slab. The transition depth is determined as the depth at which the Cocos and Nazca slabs merge (see movie in the supporting information). Spatial resolution at these depths is rather good (see supporting information Figure S1). To the right, the northern Great Arc of the Caribbean (nGAC) anomaly is visible.

up into the Nazca and Cocos plates, separated by subsequent spreading systems [Hey, 1977; Lonsdale, 2005; Meschede and Barckhausen, 2000]. The Nazca-Cocos boundary reorganized at $9.5 \mathrm{Ma}$, resulting in the Panama Fracture Zone [Hey, 1977] (Figure 2h). The Cocos plate continued subducting under Central America, and the relative plate motion between the Caribbean and Nazca plates became predominantly strike-slip [Meschede and Barckhausen, 2000], while the latter plate subducted eastward under the South America plate.

[38] Present-day subduction of the Cocos plate is evidenced by an active volcanic arc and a Wadati-Benioff zone (Figure 1b), extending northwest from the Panama Fracture Zone until its northern termination under Central Mexico [Burbach et al., 1984; Pardo and Suarez, 1995]. The Wadati-Benioff zone for the subducting Cocos slab under central Mexico dips very shallowly [Pardo and Suarez, 1995], in contrast with east from $95^{\circ} \mathrm{W}$, where the Cocos Wadati-Benioff zone dips steeply again. The different
Wadati-Benioff zone dips suggest segmentation of the subducting Cocos slab. Slab detachment has been suggested for the Cocos slab under central Mexico, based on a migrating pulse of mafic volcanism [Ferrari, 2004], while Rogers et al. [2002] use seismic tomography to suggest that the same process takes place between 200 and $500 \mathrm{~km}$ depth under Honduras. Further southeast between the Nicoya Peninsula and the Panama Fracture Zone, the Wadati-Benioff zone becomes somewhat diffuse, and east of the Panama Fracture Zone deep seismicity and active volcanism are absent. Under southern Colombia on the South America plate, Pennington [1981] identified a Wadati-Benioff zone extending to a depth of $200 \mathrm{~km}$, interpreted as Nazca lithosphere subducted eastward since 9.5 Ma (Figure 2h). The northern edge of this Wadati-Benioff zone is in good agreement with the northern terminus of volcanism [Vargas and Mann, 2013].

[39] Positive velocity anomalies along the Middle America trench, derived from Cocos and Nazca subduction, are visible 
Table 1. Subduction Zones in the Caribbean Region and the Three Representative Tectonic Reconstructions Mentioned in the Text ${ }^{\mathrm{a}}$

\begin{tabular}{l|lll} 
& \multicolumn{1}{l}{$\begin{array}{l}\text { Meschede and } \\
\text { Frisch [1998] }\end{array}$} & $\begin{array}{l}\text { Pindell and } \\
\text { Kennan [2009] }\end{array}$ & $\begin{array}{l}\text { Müller et al. } \\
{[1999]}\end{array}$ \\
\hline $\begin{array}{l}\text { Cenoizoic Subduction Zones: } \\
\text { Lesser Antilles Subduction } \\
(1100 \mathrm{~km})\end{array}$ & $1100 \mathrm{~km}$ & $1100 \mathrm{~km}$ & $1100 \mathrm{~km}$ \\
$\begin{array}{l}\text { Maracaibo Subduction } \\
(\sim 1000 \mathrm{~km})\end{array}$ & $0-300 \mathrm{~km}$ & $800 \mathrm{~km}$ & $1000 \mathrm{~km}$ \\
$\begin{array}{l}\text { Cocos and Nazca Subduction } \\
(1800 \mathrm{~km})\end{array}$ & $1800 \mathrm{~km}$ & $1800 \mathrm{~km}$ & $1800 \mathrm{~km}$ \\
$\begin{array}{l}\text { Muertos Subduction } \\
\text { (<200 km) } \\
\text { Nicaragua Rise Subduction } \\
(<200 \mathrm{~km})\end{array}$ & ? & $0-150 \mathrm{~km}$ & $200 \pm 94 \mathrm{~km}$ \\
$\begin{array}{l}\text { Mesozoic Subduction Zones: } \\
\text { Greater Caribbean Subduction } \\
\text { (1200-2100 km ) }\end{array}$ & $1000 \mathrm{~km}$ & $200 \mathrm{~km}$ & $800 \mathrm{~km}$ \\
$\begin{array}{l}\text { Farallon Subduction } \\
\text { (continuous) }\end{array}$ & Continuous & Gap & $\mathrm{X}$ \\
\hline
\end{tabular}

\begin{abstract}
${ }^{a}$ The rows denote the subduction zone in the Caribbean region, and the columns denote the three representative tectonic reconstructions. A green entry denotes that predicted amount of subduction at a particular subduction zone for a particular tectonic reconstruction matches the tomographic model. A red entry denotes a mismatch. A light blue entry indicates that the tomography is not decisive, and a cross indicates that the particular subduction zone is not featured in the tectonic reconstruction.
\end{abstract}

in the upper mantle and continue into the lower mantle (Figures 4 and 8 and movie in the supporting information). The upper mantle anomalies are fragmented and have varying dips. Starting from the northwest, the first anomaly (Co) strikes east-west, and the dip changes along strike from steep in the west to shallow in the east, consistent with the Wadati-Benioff zone of the subducting Cocos slabs under central Mexico [Pardo and Suarez, 1995]. Deeper in the mantle, the dip becomes steeper, consistent with the local tomography of [Pérez-Campos et al., 2008] and at $500 \mathrm{~km}$ depth the anomaly shifts $\sim 500 \mathrm{~km}$ to the east and merges with an anomaly further southeast (also labeled Co). This second northwest striking anomaly is located between 200 and $500 \mathrm{~km}$ depth and extends from south Mexico until the Nicoya peninsula. It was also imaged with receiver functions [Dzierma et al., 2011] and by a regional tomographic study of Mackenzie et al. [2010].

[40] Although seismicity clearly suggests subduction everywhere, except under Panama, the UU-P07 model does not image positive anomalies in the upper $200 \mathrm{~km}$ along most of the Central America trench. This can find its origin in reduced resolution and/or in a trade-off between the earthquake relocation and seismic velocity anomaly parts of the model in the joint tomographic inversion. A possible structural origin is that the young, relatively warm, and thin oceanic lithosphere that subducts presently at the Central America trench is more difficult to detect because of reduced seismic velocity contrast with the ambient mantle. The preceding subduction was of gradually older, colder material. Rogers et al. [2002] suggest a slab gap between 200 and $500 \mathrm{~km}$ depth under northern Central America. However, both the UU-P07 model and the recent tomographic model of Li et al. [2008] do not image a slab gap here.

[41] Under the Panama Block-Nazca plate boundary segment, there is neither intermediate-deep seismicity nor a positive anomaly in the top $700 \mathrm{~km}$, while detection of such a slab is within resolution range. In Costa Rica, the average convergence rate perpendicular to the trench between the Cocos plate and Central America was $73 \mathrm{~mm} / \mathrm{yr}$ during the last $9.5 \mathrm{Myr}$. The combination of this subduction with the left lateral strike-slip motion of the Nazca plate relative to Central America [Meschede and Barckhausen, 2000] leads to a $700 \mathrm{~km}$ long slab window. This is in agreement with the minimum length of the imaged slab window under Panama. Also earlier (23-9.5 Ma), subduction of the Cocos-Nazca spreading ridge might have contributed to the slab gap. Lithospheric doubling by horizontal subduction, which could also lead to a slab gap, is not suggested by both the relative motion between the Nazca plate and Panama, derived from oceanic magnetic anomalies, and the location of the lower mantle anomalies under Central America. Evidence of Neogene (with a pause during the Pliocene) alkaline and arc-tholeiitic volcanism in western Panama [De Boer et al., 1991] can be explained by asthenospheric flow through the gap. We conclude that the tomographic results agree with the subduction of Cocos lithosphere under the Central America trench to the northwest of the Panama fracture zone and of Nazca lithosphere under northern South America. Between the Cocos and Nazca slabs, tomography corroborates the presence of a slab window under Panama. Between depths of $800-900 \mathrm{~km}$, the Co and $\mathrm{Nz}$ anomalies join into the Farallon slab. Anomalies in this depth range would correspond to Farallon plate that was subducted just prior to the breakup at $\sim 23 \mathrm{Ma}$. The estimated length of the Cocos slab is $\sim 800 \mathrm{~km}$ in the upper mantle and 400 to $600 \mathrm{~km}$ in the lower mantle, depending on a $2-3$ thickening factor (Figure 8).

\section{Scoring Tectonic Reconstructions}

[42] In Table 1, we list the tectonic reconstructions mentioned in the description of Figure 2 and score them against our findings of amounts of subduction and slab 
morphology. This gives an overview of what features of the reconstructions match with the UU-P07 model. Since suggested amounts of subduction at the Muertos Trough are smaller than the resolution of the tomography, we cannot validate any tectonic reconstruction here. The three reconstructions correctly predict the amounts of subduction at the Lesser Antilles and Central America trench. However, we find that each tectonic reconstruction has one or more misfits with the tomography results: Meschede and Frisch [1998] suggest large-scale thrusting at the Maracaibo block resulting in the observed mountain building in northern Southern America, while the UU-P07 model suggests large-scale subduction here. Subduction in combination with shortening may also account for the observed uplift, without further consequences for the reconstruction. A feature of the reconstructions of both Müller et al. [1999] and Pindell and Kennan [2009], namely, subduction at the Nicaragua rise, is not corroborated by the UU-P07 model. The data suggesting the large-scale convergence at the Nicaragua rise [van Fossen and Channell, 1988] had very large error margins, and therefore, we conclude that the amount of subduction at the Nicaragua rise was small (maximally $\sim 300 \mathrm{~km}$ ), agreeing with the tectonic reconstruction of Mann [2007]. The width of the Great Arc of the Caribbean slab agrees with the prediction from reconstructions. Using slab thickening factors of 2-3, we estimate from the tomography $1200-2100 \mathrm{~km}$ of subduction at the Great Arc of the Caribbean subduction zone, which lies between the slab lengths predicted by the tectonic reconstructions; a slab length between 2000 and $3000 \mathrm{~km}$ is an inherent feature of the Pacific origin for the Caribbean plate, while for the Intra-Americas origin, this is $\sim 1000 \mathrm{~km}$. The resolution of the tomographic model is not sufficient to resolve a possible slab window in the Farallon anomaly. We conclude that the Pindell and Kennan [2009] reconstruction correctly predicts amounts of subduction for the major subduction systems in the Caribbean. Although the Meschede and Frisch [1998] reconstruction fails to correctly predict the amount of subduction at the South Caribbean margin, this seems no inherent feature and could easily be adapted.

\section{Conclusions}

[43] We compare the features and predictions of several tectonic reconstruction models of the Caribbean region with mantle structure imaged as $P$ wave velocity anomalies in model UU-P07. The size and locations of imaged positive anomalies in the upper mantle under the Caribbean confirm proposed Cenozoic subduction under the Lesser Antilles, the Central America trench, and the Maracaibo block. The tomographic results show no indication of significant recent subduction at the Muertos Trough or Eocene-Oligocene subduction between the Nicaragua rise and northern Hispaniola. Lower mantle anomalies beneath Central America confirm Farallon subduction at the Central America trench. Positive lower mantle anomalies under the central Caribbean region and Venezuela agree with Mesozoic-Eocene subduction at the Great Arc of the Caribbean.

[44] Particular inferences from our analyses of mantle structure in the context of features important for tectonic reconstructions are as follows: (1) The tomographic results agree with earlier work that classify the South AmericaCaribbean plate boundary as a STEP-type plate boundary.
(2) The south dipping slab in the upper mantle along the north(east)ern Puerto Rico margin of the Caribbean plate is brought in by westward subduction under the Lesser Antilles while staying attached to the North America margin. The imaged slab width $\sim 1100 \mathrm{~km}$ agrees with the relative displacement between the North America and Caribbean plates as recorded in the Cayman Trough. To the resulting very particular shape of the slab, we refer as the "amphitheater". (3) The plate boundary between the North and South America plates is identified at the central Lesser Antilles with a negative seismic velocity anomaly between $13^{\circ} \mathrm{N}$ and $15^{\circ}$ $\mathrm{N}$, reflecting the separation of the slabs above $\sim 400 \mathrm{~km}$ depth. The north-south opening of the plate boundary at depth may be a consequence of the development of the amphitheater. (4) In the top $700-800 \mathrm{~km}$ of the mantle, a slab window is found under Panama confirming Late Miocene to present strike-slip motion, whereas to the north, we estimate subduction of about $1100-1200 \mathrm{~km}$ of Cocos plate lithosphere since $\sim 23 \mathrm{Ma}$. (5) Slab remnants of Cretaceous-Eocene Great Arc of the Caribbean subduction are found in the lower mantle to the west of the Eocene-present Lesser Antilles slab in the upper mantle. Eocene slab detachment is in agreement with absolute plate motions. (6) The "tomographic" width of the Great Arc of the Caribbean slab, $2000 \pm 350 \mathrm{~km}$, is in agreement with tectonic reconstructions. A rough estimate of the Great Arc of the Caribbean slab length leads to values (1400 to $2000 \mathrm{~km}$ ) between the predicted $\sim 1000 \mathrm{~km}$ (Intra-Americas origin) and 2000-3000 km (Pacific origin) and cannot be used to discriminate between the two scenarios. The complexity of lower mantle structure deeper than $\sim 1100 \mathrm{~km}$ also does not lead to a firm conclusion in this respect and requires further work on the integration of tectonic evolution, absolute plate motions, and mantle structure.

[45] Acknowledgments. Thoughtful reviews by the Associate Editor Paul Mann and an anonymous reviewer greatly improved the manuscript. S.v.B. was supported by NWO project ALW.816.01.008 "How plate tearing and slabs drive reorganization of the north Caribbean plate boundary."

\section{References}

Aitken, T., P. Mann, A. Escalona, and G. L. Christeson (2011), Evolution of the Grenada and Tobago basins and implications for arc migration, Mar. Pet. Geol., 28(1), 235-258.

Amaru, M. L. (2007), Global travel time tomography with 3-D reference models, Geol. Ultraiectina, Ph.D. thesis, Utrecht University, 274 pp., Utrecht, the Netherlands.

Arden, D. D., Jr. (1975), Geology of Jamaica and the Nicaraguan Rise, in The Ocean Basins and Margins, edited by A. E. M. Nairn and F. H. Stehli, pp. 617-661, Plenum, New York.

Baes, M., R. Govers, and R. Wortel (2011), Subduction initiation along the inherited weakness zone at the edge of a slab: Insights from numerical models, Geophys. J. Int., 184, 991-1008.

Beardsley, A. G., and H. G. Avé Lallemant (2007), Oblique collision and accretion of the Netherlands Leeward Antilles to South America, Tectonics, 26, TC2009, doi:10.1029/2006TC002028.

Becker, T. W., C. Faccenna, R. J. O'Connell, and D. Giardini (1999), The development of slabs in the upper mantle: Insights from numerical and laboratory experiments, J. Geophys. Res., 104, 15,207-15,226.

Bezada, M. J., A. Levander, and B. Schmandt (2010), Subduction in the southern Caribbean: Images from finite-frequency $P$ wave tomography, J. Geophys. Res., 115, B12333, doi:10.1029/2010JB007682.

Bijwaard, H., W. Spakman, and E. R. Engdahl (1998), Closing the gap between regional and global travel time tomography, J. Geophys. Res., 103, 30055-30078.

Bird, P. (2003), An updated digital model of plate boundaries, Geochem. Geophys. Geosyst., 4(3), 1027, doi:10.1029/2001GC000252.

Bouysse, P. (1988), Opening of the Grenada back-arc basin and evolution of the Caribbean Plate during the Mesozoic and early Paleogene, Tectonophysics, 149(1-2), 121-143. 
Briden, J., D. C. Rex, A. M. Faller, and J. F. Tomblin (1979), K-Ar geochronology and paleomagnetism of volcanic rocks in the Lesser-Antilles island arc, Philos. Trans. R. Soc. London, Ser. A, 291, 485-528.

ten Brink, U. (2005), Vertical motions of the Puerto Rico Trench and Puerto Rico and their cause, J. Geophys. Res., 110, B06404, doi:10.1029/ 2004JB003459.

ten Brink, U. S., S. Marshak, and J.-L. G. Bruña (2009), Bivergent thrust wedges surrounding oceanic island arcs: Insight from observations and sandbox models of the northeastern Caribbean plate, Geol. Soc. Am. Bull., 121(11-12), 1522-1536.

Burbach, G. V., and C. Frohlich (1986), Intermediate and deep seismicity and lateral structure of subducted lithosphere in the Circum-Pacific Region, Rev. Geophys., 24, 833-874.

Burbach, G. V., C. Frolich, W. D. Pennington, and T. Matumoto (1984), Seismicity and tectonics of the subducted Cocos plate, J. Geophys. Res., 89, 7719-7735.

Burke, K. (1988), Tectonic evolution of the Caribbean, Annu. Rev. Earth Planet. Sci, 16, 201-230.

Byrne, D. B., G. Suarez, and W. R. McCann (1985), Muertos Trough subduction -Microplate tectonics in the northern Caribbean?, Nature, 317, 420-421.

Calais, E., N. Béthoux, and B. Mercier de Lépinay (1992), From transcurren faulting to frontal subduction: A seismotectonic study of the northern Caribbean plate boundary from Cuba to Puerto Rico, Tectonics, 11, 114-123.

Cammarano, F., S. Goes, P. Vacher, and D. Giardini (2003), Inferring uppermantle temperatures from seismic velocities, Phys. Earth Planet. Inter., $138,197-222$.

Clark, S. A., M. Sobiesiak, C. A. Zelt, M. B. Magnani, M. S. Miller, M. J. Bezada, and A. Levander (2008), Identification and tectonic implications of a tear in the South American plate at the southern end of the Lesser Antilles, Geochem. Geophys. Geosyst., 9, Q11004, doi:10.1029/ 2008GC002084

de Jonge, M. R., M. J. R. Wortel, and W. Spakman (1994), Regional scale tectonic evolution and the seismic velocity structure of the lithosphere and upper mantle: The Mediterranean region, J. Geophys. Res., 99, 12091-12108.

De Boer, J. Z., M. J. Defant, R. H. Stewert, and H. Bellon (1991), Evidence for active subduction below western Panama, Geology, 19, 649-652.

DeMets, C. (2001), A new estimate for present-day Cocos-Caribbean plate motion: Implications for slip along the Central American volcanic arc, Geophys. Res. Lett., 28, 4043-4046.

DeMets, C., P. E. Jansma, G. S. Mattioli, T. H. Dixon, F. Farina, R. Bilham, E. Calais, and P. Mann (2000), GPS geodetic constraints on CaribbeanNorth America plate motion, Geophys. Res. Lett., 27, 437-440.

DeMets, C., R. G. Gordon, and D. F. Argus (2010), Geologically current plate motions, Geophys. J. Int., 181(1), 1-80.

Dillon, W. P., N. T. Edgar, K. M. Scanlon, and D. F. Coleman (1996), A review of the tectonic problems of the strike-slip northern boundary of the Caribbean Plate and examination by GLORIA, in Geology of the United States' Seafloor: The View From GLORIA, edited by J. V. Gardner, M. E. Field, and D. C. Twichell, pp. 135-164, Cambridge Univ. Press, Cambridge, U. K.

Dolan, J. F., H. T. Mullins, and D. J. Wald (1998), Active tectonics of the north-central Caribbean: Oblique collision, strain partitioning, and opposing subducted slabs, in Active Strike-Slip and Collisional Tectonics of the Northern Caribbean Plate Boundary Zone, edited by J. F. Dolan and P. Mann, pp. 1-61, Geol. Soc. of Am., Boulder, Colo.

Dzierma, Y., W. Rabbel, M. M. Thorwart, E. R. Flueh, M. M. Mora, and G. E. Alvarado (2011), The steeply subducting edge of the Cocos Ridge: Evidence from receiver functions beneath the northern Talamanca Range, south-central Costa Rica, Geochem. Geophys. Geosyst., 12, Q04S30, doi:10.1029/2010GC003477.

Engdahl, E. R., R. van der Hilst, and R. Buland (1998), Global teleseismic earthquake relocation with improved travel times and procedures for depth determination, Bull. Seismol. Soc. Am., 88, 722-743.

Escalona, A., and P. Mann (2011), Tectonics, basin subsidence mechanisms, and paleogeography of the Caribbean-South American plate boundary zone, Mar. Pet. Geol., 28(1), 8-39.

Ferrari, L. (2004), Slab detachment control on mafic volcanic pulse and mantle heterogeneity in central Mexico, Geology, 32(1), 77-80

Gaherty, J. B., and B. H. Hager (1994), Compositional vs. thermal buoyancy and the evolution of subducted lithosphere, Geophys. Res. Lett., 21, $141-144$.

Goes, S., F. Cammarano, and U. Hansen (2004), Synthetic seismic signature of thermal mantle plumes, Earth Planet. Sc. Lett., 218(3-4), 403-419.

Govers, R., and M. J. R. Wortel (2005), Lithosphere tearing at STEP faults: Response to edges of subduction zones, Earth Planet. Sci. Lett., 236(1-2), $505-523$.

Granja Bruña, J. L., U. S. ten Brink, A. Carbó-Gorosabel, A. Muñoz-Martín, and M. Gómez Ballesteros (2009), Morphotectonics of the central Muertos thrust belt and Muertos Trough (northeastern Caribbean), Mar. Geol., 263(1-4), 7-33.

Grindlay, N. R., P. Mann, J. F. Dolan, and J.-P. van Gestel (2005), Neotectonics and subsidence of the northern Puerto Rico-Virgin Islands margin in response to the oblique subduction of high-standing ridges, Spec. Pap. Geol. Soc. of Am., 385, 31-60.

Gudmundsson, Ó., and M. Sambridge (1998), A regionalized upper mantle (RUM) seismic model, J. Geophys. Res., 103, 7121-7136.

Hafkenscheid, E., M. J. R. Wortel, and W. Spakman (2006), Subduction history of the Tethyan region derived from seismic tomography and tectonic reconstructions, J. Geophys. Res., 111, B08401, doi:10.1029/ 2005JB003791.

Hey, R. (1977), Tectonic evolution of the Cocos-Nazca spreading center, Geol. Soc. Am. Bull., 88, 1404-1420.

Hörnle, K., F. Hauff, and P. van de Bogaard (2004), A 70 Myr history (139-69 Ma) for the Caribbean large igneous province, Geology, 32, 697-700.

Jaillard, E., P. Soler, G. Carlier, and T. Mourier (1990), Geodynamic evolution of the northern and central Andes during early to middle Mesozoic times: A Tethyan model, J. Geol. Soc. London, 147, 1009-1022.

James, K. H. (2009), Evolution of Middle America and the in situ Caribbean Plate model, Geol. Soc. Spec. Publ., 328(1), 127-138.

Jansma, P., A. Lopez, G. Mattioli, C. DeMets, T. Dixon, P. Mann, and E. Calais (2000), Microplate tectonics in the northeastern Caribbean as constrained by Global Positioning (GPS) geodesy, Tectonics, 19, 1021-1037.

Jolly, W. T., E. G. Lidiak, and A. P. Dickin (2008), The case for persistent southwest-dipping Cretaceous convergence in the northeast Antilles: Geochemistry, melting models, and tectonic implications, Geol. Soc Am. Bull., 120(7-8), 1036-1052.

Kearey, P. (1974), Gravity and seismic reflection investigations into the crustal structure of the Aves Ridge, eastern Caribbean, Geophys. J. R. Astron. Soc., 38, 435-448.

Kellog, J. N., and V. Vega (1995), Tectonic development of Panama, Costa Rica, and the Colombian Andes: Constraints from global positioning system geodetic studies and gravity, in Geologic and Tectonic Development of the Caribbean Plate Boundary in Southern Central America, edited by P. Mann, pp. 75-90, Geol. Soc. of Am., Boulder, Colo.

Kennett, B. L. N., E. R. Engdahl, and R. Buland (1995), Constraints on seismic velocities in the Earth from traveltimes, Geophys. J. Int. 122(1), 108-124

Kroehler, M. E., P. Mann, A. Escalona, and G. L. Christeson (2011), Late Cretaceous-Miocene diachronous onset of back thrusting along the South Caribbean deformed belt and its importance for understanding processes of arc collision and crustal growth, Tectonics, 30, TC6003, doi:10.1029/2011TC002918.

Leroy, S., A. Mauffret, P. Patriat, and B. M. de Lepinay (2000), An alternative interpretation of the Cayman trough evolution from a reidentification of magnetic anomalies, Geophys. J. Int., 141(3), 539-557.

Li, C., R. D. van der Hilst, E. R. Engdahl, and S. Burdick (2008), A new global model for $P$ wave speed variations in Earth's mantle, Geochem. Geophys. Geosyst., 9, Q05018, doi:10.1029/2007GC001806.

Lonergan, L., and N. White (1997), Origin of the Betic-Rif mountain belt, Tectonics, $16,504-522$

Lonsdale, P. (2005), Creation of the Cocos and Nazca plates by fission of the Farallon Plate, Tectonophysics, 404(3-4), 237-264.

Macdonald, R., C. J. Hawkesworth, and E. Heath (2000), The Lesser Antilles volcanic chain: A study in arc magmatism, Earth Sci. Rev., 49(1-4), 1-76.

MacKenzie, L. S., G. A. Abers, S. Rondenay, and K. M. Fischer (2010), Imaging a steeply dipping subducting slab in Southern Central America, Earth Planet. Sci. Lett., 296(3-4), 459-468.

Mann, P. (2007), Overview of the tectonic history of northern Central America, in Geologic and Tectonic Development of the Caribbean Plate Boundary in Northern Central America, Spec. Pap. Geol. Soc. Am., 428, 1-37.

Mann, P., F. W. Taylor, R. L. Edwards, and T. L. Ku (1995), Actively evolving microplate formation by oblique collision and sideways motion along strike-slip faults: An example from the northeastern Caribbean plate margin, Tectonophysics, 246(1-3), 1-69.

Mann, P., E. Calais, J. C. Ruegg, C. DeMets, P. E. Jansma, and G. S. Mattioli (2002), Oblique collision in the northeastern Caribbean from GPS measurements and geological observations, Tectonics, 21, 1057-1083.

McCann, W. R., and W. C. Pennington (1990), Seismicity, large earthquakes, and the margin of the Caribbean plate, in The Caribbean Region, edited by G. Dengo and J. D. Case, pp. 291-305, Geol. Soc. of Am., Boulder, Colo.

McCann, W., and L. Sykes (1984), Subduction of aseismic ridges beneath the Caribbean plate: Implications for the tectonics and seismic potential of the northeastern Caribbean, J. Geophys. Res., 89, 4493-4519.

Meschede, M., and U. Barckhausen (2000), Plate tectonic evolution of the Cocos-Nazca spreading center, in Proc. ODP, Sci. Results, 170, edited by E. A. Silver, G. Kimura and T. H. Shipley, Ocean Drilling 
Program 170, College Station, TX, 1-10, doi:10.2973/odp.proc. sr.170.009.2000.

Meschede, M., and W. Frisch (1998), A plate-tectonic model for the Mesozoic and Early Cenozoic history of the Caribbean plate, Tectonophysics, 296(3-4), 269-291.

Miller, M. S., A. Levander, F. Niu, and A. Li (2009), Upper mantle structure beneath the Caribbean-South American plate boundary from surface wave tomography, J. Geophys. Res., 114, B01312, doi:10.1029/2007JB005507.

Molnar, P., and L. R. Sykes (1969), Tectonics of the Caribbean and middle America regions from focal mechanisms and seismicity, Geol. Soc. Am. Bull., 80, 1639-1684.

Müller, R. D., and W. H. F. Smith (1993), Deformation of the oceanic crust between the North American and South American Plates, J. Geophys. Res., 98, 8275-8291.

Müller, R. D., J.-Y. Royer, S. C. Cande, W. R. Roest, and S. Maschenkov (1999), New constraints on the Late Cretaceous/Tertiary plate tectonic evolution of the Caribbean, in Caribbean Basins, edited by P. Mann, pp. 33-59, Elsevier Sci., Amsterdam.

Müller, R. D., M. Sdrolias, C. Gaina, and W. R. Roest (2008), Age, spreading rates, and spreading asymmetry of the world's ocean crust, Geochem. Geophys. Geosyst., 9, Q04006, doi:10.1029/2007GC001743.

Niu, F., T. Bravo, G. Pavlis, F. Vernon, H. Rendon, M. Bezada, and A. Levander (2007), Receiver function study of the crustal structure of the southeastern Caribbean plate boundary and Venezuela, J. Geophys. Res., 112, 11308, doi:10.1029/2006JB004802.

Pardo, M., and G. Suarez (1995), Shape of the subducted Rivera and Cocos plates in southern Mexico: Seismic and tectonic implications, J. Geophys. Res., 100, 12357-12373.

Pennington, W. D. (1981), Subduction of the eastern Panama Basin and seismotectonics of northwestern South America, J. Geophys. Res., 86, 10753-10770.

Pérez-Campos, X., Y. Kim, A. Husker, P. M. Davis, R. W. Clayton, A. Iglesias, J. F. Pacheco, S. K. Singh, V. C. Manea, and M. Gurnis (2008), Horizontal subduction and truncation of the Cocos Plate beneath central Mexico, Geophys. Res. Lett., 35, L18303, doi:10.1029/2008GL035127.

Pichot, T., M. Patriat, G. K. Westbrook, T. Nalpas, M. A. Gutscher, W. R. Roest, E. Deville, M. Moulin, D. Aslanian, and M. Rabineau (2012), The Cenozoic tectonostratigraphic evolution of the Barracuda Ridge and Tiburon Rise, at the western end of the North America-South America plate boundary zone, Mar. Geol., 303-306, 154-171.

Pindell, J. L., and S. F. Barrett (1990), Geologic evolution of the Caribbean: A plate-tectonic perspective, in The Geology of North America, vol. H, The Caribbean Region, edited by G. Dengo and J. E. Case, pp. 405-432, Geol. Soc. of Am., Boulder, Colo.

Pindell, J. L., and L. Kennan (2009), Tectonic evolution of the Gulf of Mexico, Caribbean and northern South America in the mantle reference frame: An update, in The Origin and Evolution of the Caribbean Plate, edited by K. H. James, M. A. Lorente, and J. L. Pindell, Geol. Soc. Spec. Publ., 328, 1-55.

Pindell, J. L., S. C. Cande, W. C. Pitman, III, D. B. Rowley, J. F. Dewey, J. LaBrecque, and W. Haxby (1988), A plate-kinematics framework for models of Caribbean evolution, Tectonophysics, 155, 121-138.

Pindell, J., L. Kennan, K.-P. Stanek, W. V. Maresch, and G. Draper (2006), Foundations of Gulf of Mexico and Caribbean evolution: Eight controversies resolved, Geol. Acta, 4(1-2), 303-341.

Richards, M. A., and D. C. Engebretson (1992), Large-scale mantle convection and the history of subduction, Nature, 355(6359), 437-440.

Rogers, R., H. Karason, and R. van der Hilst (2002), Epeirogenic uplift above a detached slab in northern Central America, Geology, 30, 1031-1034.

Rogers, R., P. Mann, and P. Emmet (2007), Tectonic terranes of the Chortis block based on integration of regional aeromagnetic and geologic data, Spec. Pap. Geol. Soc. of Am., 428, 65-88.

Ross, M. I., and C. R. Scotese (1988), A hierarchical tectonic model of the Gulf of Mexico and Caribbean region, Tectonophysics, 155, 139-168.

Schell, B. A., and A. C. Tarr (1978), Plate tectonics of the northeastern Caribbean, Geol. Mijnbouw, 57, 319-24.
Schellart, W. P. (2004a), Quantifying the net slab pull force as a driving mechanism for plate tectonics, Geophys. Res. Lett., 31, L07611, doi:10.1029/2004GL019528.

Schellart, W. P. (2004b), Kinematics of subduction and subduction-induced flow in the upper mantle, J. Geophys. Res., 109, B07401, doi:10.1029/ 2004JB002970.

Spakman, W., and H. Bijwaard (2001), Optimization of cell parameterizations for tomographic inverse problems, Pure Appl. Geophys., 158(8), $1401-1423$.

Spakman, W., and R. Wortel (2004), A tomographic view on Western Mediterranean Geodynamics, in The TRANSMED Atlas, The Mediterranean Region from Crust to Mantle, edited by C. Cavazza et al., pp. 31-52, Springer, Berlin, Heidelberg, Germany.

Sykes, L. R., and M. Ewing (1965), The seismicity of the Caribbean region, J. Geophys. Res., 70, 5065-5074.

Sykes, L. R., W. R. McCann, and A. L. Kafka (1982), Motion of the Caribbean plate during last 7 million years and implications for earlier Cenozoic movements, J. Geophys. Res., 87, 10656-10676.

Taboada, A., L. Rivera, A. Fuenzalida, A. Cisternas, H. Philip, H. Bijwaard, J. Olaya, and C. Rivera (2000), Geodynamics of the northern Andes: Subductions and intracontinental deformation (Colombia), Tectonics, 19, 787-813.

Torsvik, T. H., R. D. Müller, R. Van der Voo, B. Steinberger, and C. Gaina (2008), Global plate motion frames: Toward a unified model, Rev. Geophys., 46, RG3004, doi:10.1029/2007RG000227.

Trenkamp, R., J. N. Kellogg, J. T. Freymueller, and H. P. Mora (2002), Wide plate margin deformation, southern Central America and northwestern South America, CASA GPS observations, J. South Am. Earth Sci., 15(2), 157-171.

VanDecar, J. C., R. M. Russo, D. E. James, W. B. Ambeh, and M. Franke (2003), Aseismic continuation of the Lesser Antilles slab beneath continental South America, J. Geophys. Res., 108(B1), 2043, doi:10.1029/ 2001JB000884.

van der Hilst, R. D. (1990), Tomography with P, PP and pP delay-time data and the three dimension mantle structure below the Caribbean region, Geol. Ultraiectina, Ph.D. thesis, Utrecht University, 67, 250 pp., Utrecht, the Netherlands.

van der Hilst, R., and P. Mann (1994), Tectonic implications of tomographic images of subducted lithosphere beneath northwestern South America, Geology, 22, 451-454.

van der Hilst, R. D., and W. Spakman (1989), Importance of reference model in linearized tomography and images of subduction below the Caribbean plate, Geophys. Res. Lett., 16, 1093-1096.

van der Hilst, R. D., S. Widiyantoro, and E. R. Engdahl (1997), Evidence for deep mantle circulation from global tomography, Nature, 386(6625), $578-584$.

van der Meer, D. G., W. Spakman, D. J. J. van Hinsbergen, M. L. Amaru, and T. H. Torsvik (2010), Towards absolute plate motions constrained by lower-mantle slab remnants, Nat. Geosci., 3(1), 36-40.

van Fossen, M. C., and J. E. T. Channell (1988), Paleomagnetism of Late Cretaceous and Eocene limestones and chalks from Haiti tectonic interpretations, Tectonics, 7, 601-612.

van Hinsbergen, D. J. J., M. A. Iturralde-Vinent, P. W. G. van Geffen, A. García-Casco, and S. van Benthem (2009), Structure of the accretionary prism, and the evolution of the Paleogene northern Caribbean subduction zone in the region of Camagüey, Cuba, J. Struct. Geol., 31, 1130-1144.

Vargas, C. A., and P. Mann (2013), Tearing and breaking off of subducted slabs as the result of collision of the Panama Arc-indenter with northwestern South America, Bull. Seismol. Soc. Am., 103(3), 2025-2046.

Wadge, G., and J. B. Shepherd (1984), Segmentation of the Lesser-Antilles subduction zone, Earth Planet. Sci. Lett., 71, 297-304.

Weber, J. C., T. H. Dixon, C. DeMets, W. B. Ambeh, P. Jansma, G. Mattioli, J. Saleh, G. Sella, R. Bilham, and O. Perez (2001), GPS estimate of relative motion between the Caribbean and South American plates, and geologic implications for Trinidad and Venezuela, Geology, 29(1), 75-78. 